\title{
Efficient Control of DC Microgrid with Hybrid PV-Fuel Cell and Energy Storage Systems
}

\author{
Subramanian Vasantharaj ${ }^{1}$, Vairavasundaram Indragandhi ${ }^{1}{ }^{\mathbb{D}}$, Vairavasundaram Subramaniyaswamy ${ }^{2}$, \\ Yuvaraja Teekaraman ${ }^{3, *(\mathbb{D})}$, Ramya Kuppusamy ${ }^{4}$ and Srete Nikolovski ${ }^{5}$ (i) \\ 1 School of Electrical Engineering, Vellore Institute of Technology, Vellore City 632014, India; \\ vasantharaj118@gmail.com (S.V.); indragandhi.v@vit.ac.in (V.I.) \\ 2 School of Computing, SASTRA Deemed University, Thanjavur 613401, India; \\ vsubramaniyaswamy@gmail.com \\ 3 MOBI-Mobility, Logistics and Automotive Technology Research Centre, Vrije Universiteit Brussel, Ixelles, \\ 1050 Brussels, Belgium \\ 4 Department of Electrical and Electronics Engineering, Sri Sairam College of Engineering, \\ Bangalore City 562106, India; ramyapks26@ieee.org \\ 5 Power Engineering Department, Faculty of Electrical Engineering, Computer Science and Information \\ Technology, University of Osijek, 31000 Osijek, Croatia; srete.nikolovski@ferit.hr \\ * Correspondence: yuvarajastr@ieee.org
}

check for updates

Citation: Vasantharaj, S.; Indragandhi, V.; Subramaniyaswamy, V.; Teekaraman, Y.; Kuppusamy, R.;

Nikolovski, S. Efficient Control of DC Microgrid with Hybrid PV-Fuel Cell and Energy Storage Systems. Energies 2021, 14, 3234. https://doi.org/ $10.3390 /$ en14113234

Academic Editors: Carlos Pozo and Antonino S. Aricò

Received: 26 April 2021

Accepted: 28 May 2021

Published: 1 June 2021

Publisher's Note: MDPI stays neutral with regard to jurisdictional claims in published maps and institutional affiliations.

Copyright: (c) 2021 by the authors. Licensee MDPI, Basel, Switzerland. This article is an open access article distributed under the terms and conditions of the Creative Commons Attribution (CC BY) license (https:/ / creativecommons.org/licenses/by/ $4.0 /)$.

\begin{abstract}
Direct current microgrids are attaining attractiveness due to their simpler configuration and high-energy efficiency. Power transmission losses are also reduced since distributed energy resources (DERs) are located near the load. DERs such as solar panels and fuel cells produce the DC supply; hence, the system is more stable and reliable. DC microgrid has a higher power efficiency than AC microgrid. Energy storage systems that are easier to integrate may provide additional benefits. In this paper, the DC micro-grid consists of solar photovoltaic and fuel cell for power generation, proposes a hybrid energy storage system that includes a supercapacitor and lithium-ion battery for the better improvement of power capability in the energy storage system. The main objective of this research work has been done for the enhanced settling point and voltage stability with the help of different maximum power point tracking (MPPT) methods. Different control techniques such as fuzzy logic controller, neural network, and particle swarm optimization are used to evaluate PV and FC through DC-DC boost converters for this enhanced settling point. When the test results are perceived, it is evidently attained that the fuzzy MPPT method provides an increase in the tracking capability of maximum power point and at the same time reduces steady-state oscillations. In addition, the time to capture the maximum power point is $0.035 \mathrm{~s}$. It is about nearly two times faster than neural network controllers and eighteen times faster than for PSO, and it has also been discovered that the preferred approach is faster compared to other control methods.
\end{abstract}

Keywords: MPPT; fuzzy logic controller (FLC); solar photovoltaic (PV); fuel cell (FC); DC-link; artificial neural network (ANN); particle swarm optimization (PSO)

\section{Introduction}

The global energy demand is steadily increasing. Traditional energy sources emit greenhouse gases, so non-traditional energy sources such as solar PV and wind turbines were developed to be renewable, abundant in nature, cost-efficient, and widely used. Instead, use a source as FC has in this ever-increasing power demand. The majority of rural areas do not have access to reliable electricity. The initial investment cost to electrify rural areas was very high. Still, with the aid of DC microgrids based on renewable energy sources (RES) such as solar PV and FC with energy storage systems (ESS), implementation is simple and cost-effective [1,2]. In this current scenario, DC microgrids are more popular because of easy interfacing with distribution generation without interlinking AC/DC and DC/AC 
transformation stages. They do not have any reactive power and complex frequency issues. DC/DC converters are important for the integration of distribution generation in DC microgrids [3]. Buck converters, boost converters, and buck-boost converters [4] are the three types of DC/DC converters commonly used. Buck converter produces a controlled output voltage, which is lesser than the input voltage; for a boost converter, the controlled output voltage is greater than the input voltage; similarly, for a buck-boost converter, the controlled output voltage is lesser or greater than the input voltage. Compared to an AC micro-grid, connecting RESs to a common DC bus has many advantages, including greater performance and accuracy and the elimination of frequency and phase control requirements [5,6]. Similarly, bi-directional DC/DC converters are used in this dc microgrid to maintain high reliability and load power supply [7]. The ultra-capacitor is preferred with battery combinations because of low power density battery cannot reimburse for fast power fluctuation $[8,9]$. Mohammed T. Arif proposed a significance of storage on solar PV system for residential load considering PV as renewable energy generator [10].

In the FC, an electrolyzer produces hydrogen gas by the process called electrolysis. The gas tanks and metal hydride tanks are used to store the hydrogen gas in the FC. Compared to gas tanks, metal hydride is more expensive and bigger in size, but the safety against accidents is high, and that's why it is essential for self-governing systems installed in remote areas [11]. In this paper, the maximum power point tracking (MPPT) of solar PV and FC are achieved. To track the maximum power, different types of MPPT techniques are used, namely perturb and observe (P and O), incremental conductance (INC), FLC, ANN, and the particle swarm optimization (PSO) algorithm. In these different MPPT methods, $\mathrm{P}$ and $\mathrm{O}$ MPPT technique is most frequently used, and it is proposed for both $\mathrm{PV}$ and FC systems [12,13]. In this paper, different types of MPPT [14-16] techniques (FLC, ANN and PSO) are used for attaining the maximum power of PV and FC system and embrace all hybrid power (PV-FC) with battery and ultra-capacitor power at DC link. Saleh Elkelani Babaa [17] has presented an overview of different MPPT methods for PV systems. Luigi Costano and Massimo Vitelli [18] have designed a single-stage grid-connected PV system in mind. Its efficiency is compared numerically to that of the commonly used perturb and observe (P and O) MPPT technique. Mohammed Junaid Khan [19] has designed a fuzzy logic-based MPPT controller for PV and FC applications.

Figure 1 shows the distributed RES, ESS, DC load with grid-connected voltage source converter. DC microgrids have more advantages such as high efficiency, reliability, and low environmental pollution than AC microgrid and do not have frequency, reactive power issues. Hence, it is easy to link with DC micro sources.

A study of different controllers such as FLC, NN, and PSO algorithm for hybrid DC microgrid has been made in this paper. With the assistance of various controllers, the settling time of power is observed. It is determined that fuzzy provides the most effective MPPT system compared to other control techniques. The organization of this research is as follows. Section 2 presents the solar PV and FC mathematical modeling. Section 3 explains the different MPPT control techniques such as FLC, ANN, and PSO algorithm to control the DC bus voltage, and the simulation results are presented in Section 4. Section 5 illustrates the conclusion and future scope of the hierarchical control structure. 


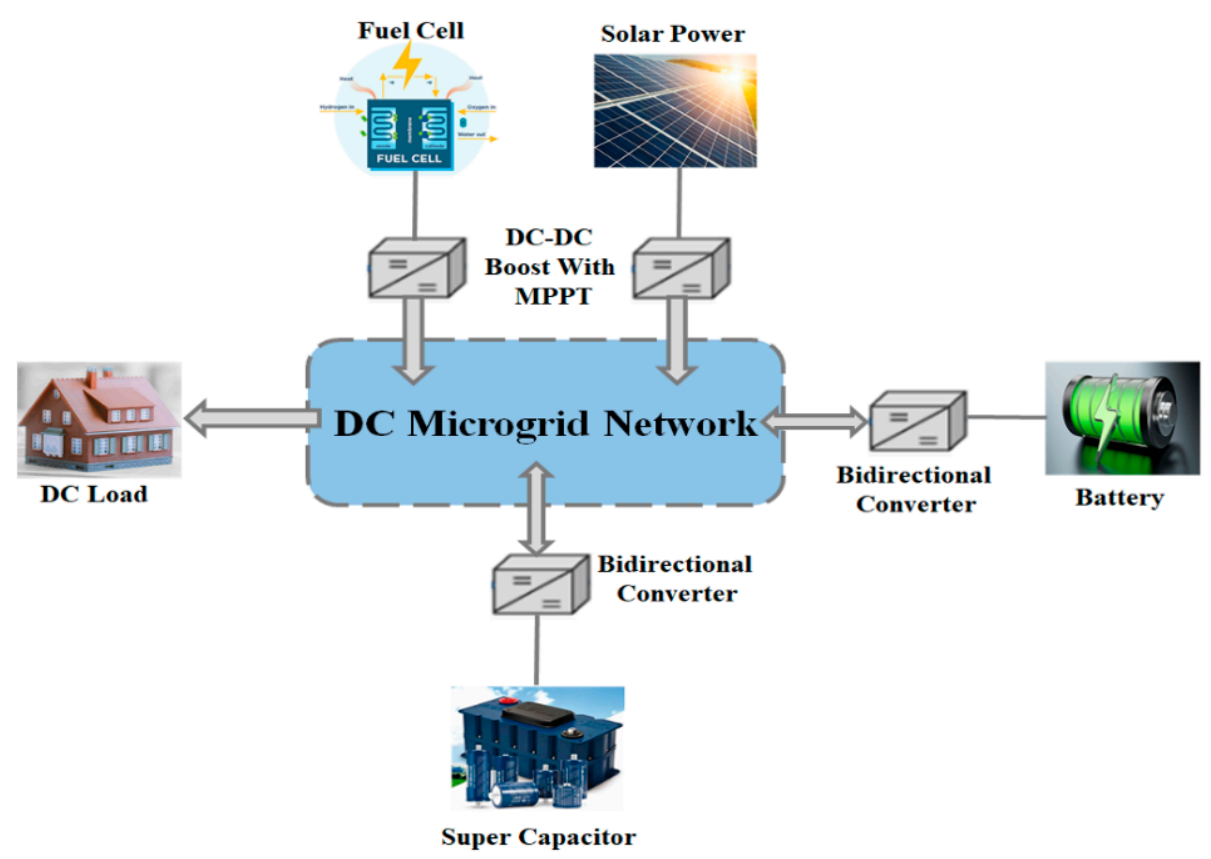

Figure 1. Schematic Diagram of DC Microgrid consists of Renewable Energy Sources (RESs) and Energy Storage Systems (ESS).

\section{Mathematical Model of Solar PV and Fuel Cell}

The mathematical equations are modeled and designed using MATLAB/Simulink (2019a, The Mathwork, Inc., Natick, MA, USA) for PV and FC, which is illuminated as follows:

\subsection{Modelling of Solar PV}

PV cells are electrical devices that transform solar energy into electricity using semiconducting devices that demonstrate the photovoltaic effect. The photovoltaic cell is used to describe electrical variables such as current, voltage, and resistance as they change in response to sunlight. The equivalent circuit of a solar cell is shown in Figure 2. When an electron collides with another electron in its bound state, electron conduction occurs, and these electrons are energized by the base energy provided by the semiconductor's bandgap. The equivalent circuit of PV [20] module contains a diode, light-created source, and resistance connected in parallel. Figure 3 shows the P-V and I-V characteristics [21-23] of solar cell, which is conditioned and screened for various irradiances at $\mathrm{T}=25^{\circ} \mathrm{C}$. The following Equations (1)-(4) represent the mathematical equations for modeling solar cells.

$$
\begin{gathered}
\mathrm{I}=\mathrm{I}_{\mathrm{ph}}-\mathrm{I}_{\mathrm{d}}\left[\exp \left(\frac{\mathrm{qV}}{\mathrm{k}_{\mathrm{b}} \mathrm{TA}}\right)-1\right] \\
\mathrm{I}_{\mathrm{sh}}=\frac{\left[\mathrm{V}+\left(\mathrm{I} * \mathrm{R}_{\mathrm{s}}\right)\right]}{\mathrm{R}_{\mathrm{sh}}} \\
\mathrm{I}_{\mathrm{ph}}=\mathrm{I}_{\mathrm{rr}}\left[\mathrm{I}_{\mathrm{sc}}+\mathrm{k}_{\mathrm{i}}\left(\mathrm{T}_{\mathrm{op}}-\mathrm{T}_{\text {ref }}\right)\right] \\
\mathrm{I}_{\mathrm{d}}=\mathrm{I}_{\mathrm{rr}}\left[\frac{\mathrm{T}_{\mathrm{op}}}{\mathrm{T}_{\mathrm{ref}}}\right]^{3} \exp \left(\frac{\mathrm{qE} \mathrm{g}_{\mathrm{g}}}{\mathrm{kQA}}\left[\frac{1}{\mathrm{~T}_{\text {ref }}}-\frac{1}{\mathrm{~T}_{\mathrm{op}}}\right]\right)
\end{gathered}
$$

where, $\mathrm{I}=$ total current $(\mathrm{A}) ; \mathrm{V}=$ output voltage $(\mathrm{V}) ; \mathrm{T}=$ temperature $\left({ }^{\circ} \mathrm{C}\right) ; \mathrm{q}=$ electron charge; $\mathrm{k}_{\mathrm{i}}=$ short-circuit temperature coefficient; $\mathrm{I}_{\mathrm{sh}}=$ shunt resistance current; $\mathrm{R}_{\mathrm{s}}=$ Series Resistance; $\mathrm{R}_{\mathrm{sh}}=$ Shunt Resistance; $\mathrm{k}_{\mathrm{b}}=$ open-circuit voltage temperature coefficient and $\mathrm{k}=$ Boltzmann's constant; $\mathrm{A}$ = ideality factor; $\mathrm{I}_{\mathrm{ph}}=$ load current; $\mathrm{I}_{\mathrm{d}}=$ diode 
current; $\mathrm{I}_{\mathrm{rr}}=$ saturation current at $\mathrm{T}_{\text {ref }} ; \mathrm{I}_{\mathrm{sc}}=$ short-circuit current at reference condition; $\mathrm{T}_{\text {ref }}=$ reference temperature; $\mathrm{Q}=$ total electron charge; $\mathrm{E}_{\mathrm{g}}=$ band-gap energy.

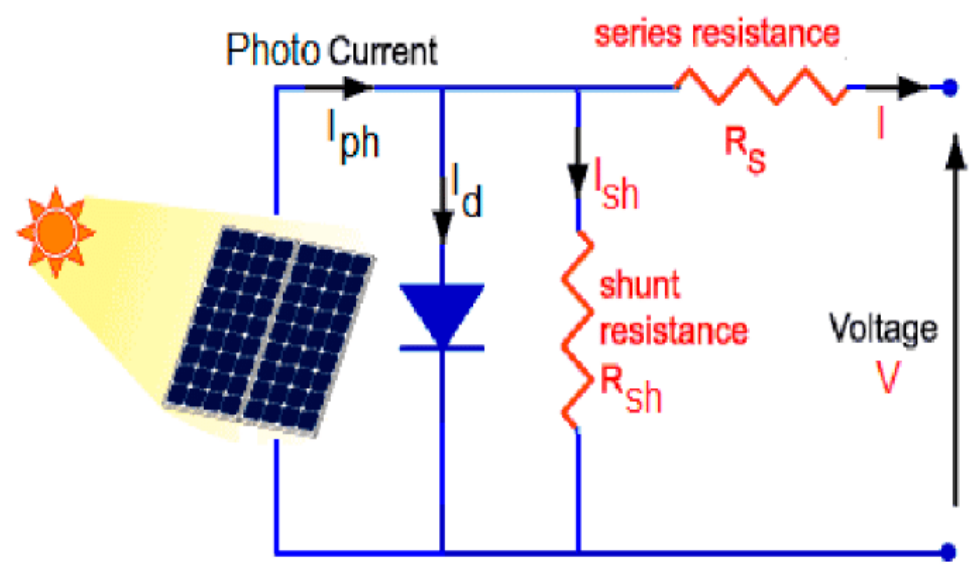

Figure 2. Solar Cells equivalent circuit.

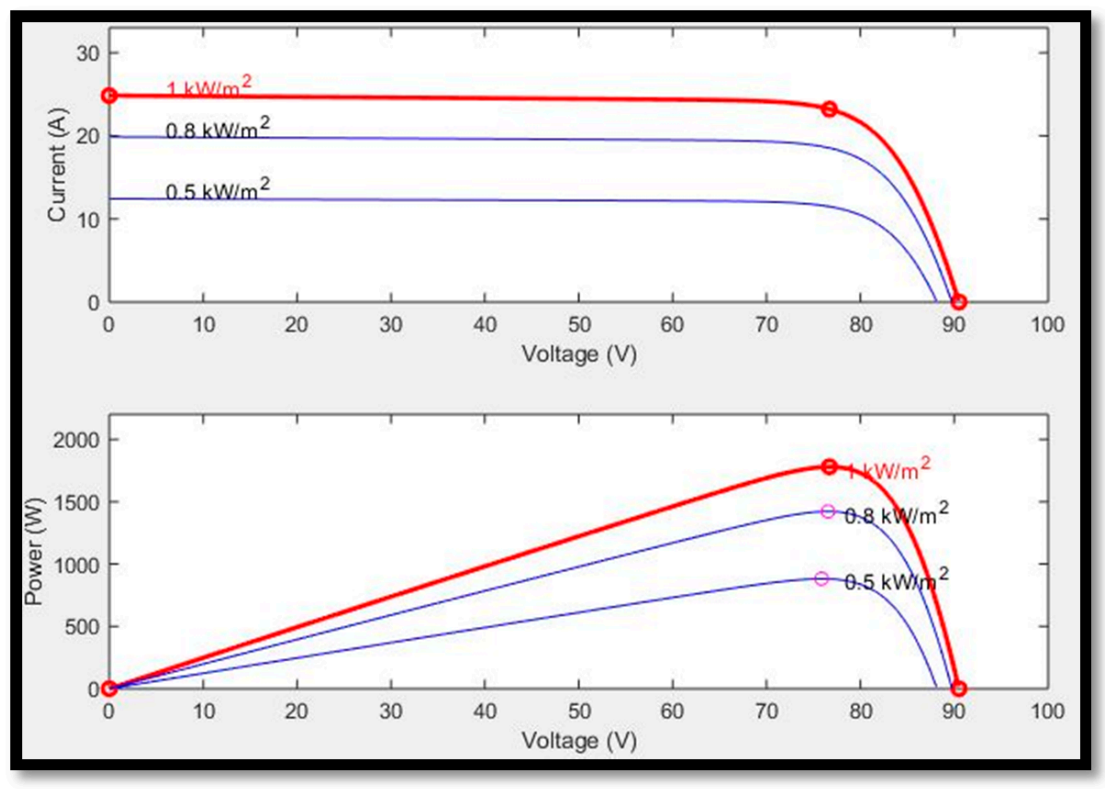

Figure 3. $\mathrm{P}-\mathrm{V}$ and $\mathrm{I}-\mathrm{V}$ Characteristics of solar cell for Different Irradiance for constant $\mathrm{T}=25^{\circ} \mathrm{C}$.

\subsection{FC Mathematical Model}

The FC [24] consists of Proton exchange membrane (PEM) [25-27], catalyst layer (CL), gas diffusion layer (GDL), gas channel (GC), and current collector (CC) of both anode and cathode. Figure 4 illustrates the proton exchange membrane fuel cell (PEMFC).

\subsubsection{Model Equations of FC}

FC's fundamental model includes mass, thermal energy, momentum, organisms, and charge. This FC model is based on five equations. These equations are combined to form an electrochemical process to express reaction kinetics and electro-osmotic drag during the polymer electrolyte process. Equations (5)-(10) represent the five equations for this FC model in vector form. 


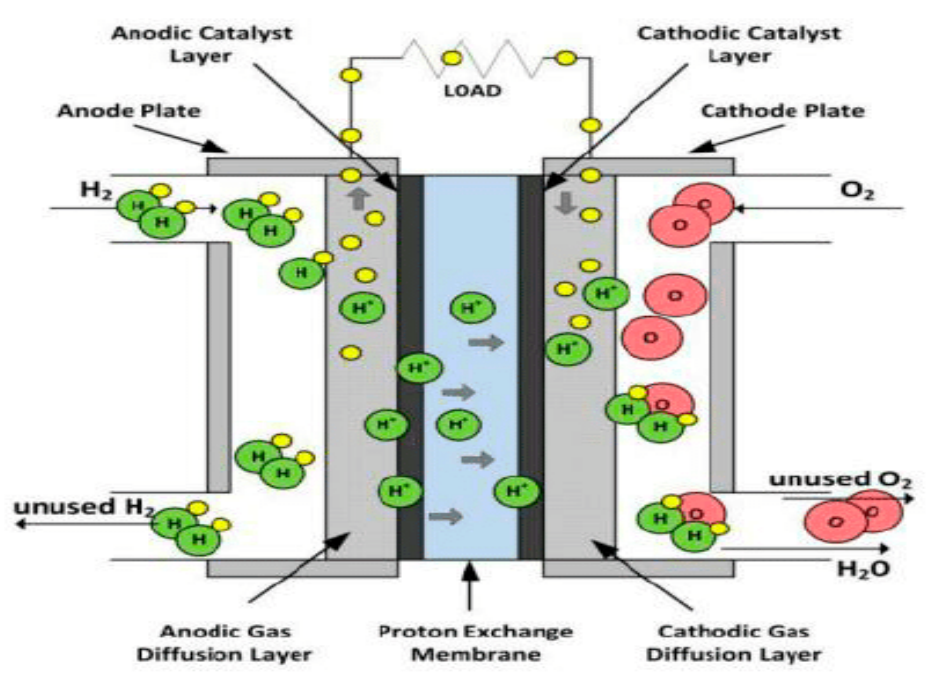

Figure 4. Schematic illustration of proton exchange membrane fuel cell (PEMFC).

\subsubsection{Continuity Equation}

The electrodes present in the FC are made up of carbon fiber or carbon cloth. The reactant gases are spread over the $\mathrm{CL}$, and the electrodes are restrained as a porous medium everywhere. The continuity equation for the porosity with the help of electrodes $(\varepsilon)$ has given in Equation (5).

$$
\left(\frac{\partial \varepsilon \rho}{\partial \mathrm{t}}\right)+\nabla \times(\varepsilon \rho \mathrm{U})=0
$$

where $\nabla=$ differential operator of a vector, $\rho=$ liquid density, $\varepsilon=$ porosity, $\mathrm{U}=$ floating speed vector and $t=$ time.

\subsubsection{Momentum Conservation}

Navier-Stokes equation has given in Equation (6) and designed for a Newtonian fluid.

$$
\left(\frac{\partial(\varepsilon \rho \mathrm{U})}{\partial \mathrm{t}}\right)+\nabla \cdot\left(\varepsilon \rho \mathrm{U}^{2}\right)=-\varepsilon \nabla \mathrm{p}+\varepsilon \mathrm{F}+\nabla \cdot(\varepsilon \tau)-\frac{\varepsilon^{2} \mu \mathrm{U}}{\mathrm{k}}
$$

where $\rho=$ pressure; $\tau=$ stress tensor; $F=$ floating mass vector; $\mu=$ liquid viscidity degree; $\mathrm{k}=$ permeate ratio of the liquid by porous medium.

\subsubsection{Conversion of Charge Equation}

PEMFC is used in CL to conduct electrochemical reactions. The charge equations are an integral part of the FC, and this equation consists of two equations: electron removal above conductive solid phase and proton transference above the membrane. The oxygen diffusion flux (ODF) on the catalyst surface is used to calculate the current density (CD) that circulates along with CL. The CL's two-dimensional Poisson's equation is as follows:

$$
\nabla \cdot \mathrm{i}=0
$$

The sum of phase currents of solid $\left(i_{s}\right)$ and membrane $\left(i_{m}\right)$ during $C L$ is equal to the total current (i), which is given in the following equation,

$$
\mathrm{i}=\mathrm{i}_{\mathrm{s}}+\mathrm{i}_{\mathrm{m}}
$$

Using Ohm's law, the transfer current density $\left(\mathrm{J}_{\mathrm{t}}\right)$ with solid surface tension is given by,

$$
\mathrm{J}_{\mathrm{t}}=-\nabla \cdot-\left(\sigma_{\mathrm{s}} \nabla \varphi_{\mathrm{s}}\right)=\nabla \cdot\left(-\sigma_{\mathrm{m}} \nabla \varphi_{\mathrm{m}}\right)
$$


where $J_{t}=$ transfer current density at time $t, \sigma_{s}=$ solid phase surface tension, $\sigma_{\mathrm{m}}=$ membrane phase surface tension, $\varphi_{\mathrm{s}}=$ solid phase flux, $\varphi_{\mathrm{m}}=$ membrane phase flux.

\subsubsection{Electrochemical Reaction Dynamics equation}

The current density at time $\left(\mathrm{J}_{\mathrm{t}}\right)$ is a classification of electrochemical reaction velocity, the concentration of species, and potential among the phase of the membrane and solid. The expression for Butler-Volmer (B-V) has expressed below,

$$
\mathrm{J}_{\mathrm{t}}=\mathrm{J}_{\mathrm{o}}\left\{\exp \left[\frac{\alpha_{\mathrm{a}} \mathrm{F}}{\mathrm{RT}}\left(\Phi_{\mathrm{s}}-\Phi_{\mathrm{m}}\right)\right]-\exp \left[\frac{\alpha_{\mathrm{c}} \mathrm{F}}{\mathrm{RT}}\left(\Phi_{\mathrm{s}}-\Phi_{\mathrm{m}}\right)\right]\right\} \prod_{j=1}^{\mathrm{N}}[\Lambda]^{\alpha j}
$$

where, $\mathrm{F}=$ Faraday's constant, $\mathrm{R}=$ electrical resistance, $\mathrm{J}_{0}=$ exchange current density, $\alpha j=$ charge transfer coefficient, $\alpha_{a}$ and $\alpha_{c}=$ transfer coefficients of cathode and anode. $\Lambda=$ mol concentration of the reactant.

\section{MPPT Techniques}

The efficient yield of solar PV and FC has developed via different MPPT methods. Various types of MPPT techniques are there. From that, the utmost familiar MPPT methods are perturb and observe (P and O), incremental conductance technique (INC), the FLC, ANN, and particle swarm optimization (PSO) control methods. In this paper, power has been transferred to load with the help of MPPT to extract maximum power from hybrid (PV-FC) DC microgrid. DC/DC boost converter performs as an interface among load and hybrid (PV-FC) sources. The maximum power has been obtained by changing the duty cycle of the DC/DC converter with respect to the load impedance. Hence, the MPPT techniques for solar PV and FC are necessary to sustain the module functioning at its MPPT.

\subsection{Particle Swarm Optimization (PSO)}

Kennedy and Eberhart founded PSO [28-30] as an evolutionary computation strategy. Birds penetrating for food stimulate the PSO. Flocking is a mechanism through which birds classify their food sources, and it was through these flock activities, the PSO process was discovered. The search space directs moving particles to their known positions. When a better position is found, it will be used to direct the flock's movement. Since the method is ongoing, as is the execution, the appropriate outcome can be trusted but not guaranteed. The difference between PSO and conventional evolutionary computation approaches is that particle velocities are tuned while individual evolutionary positions are replaced; it's as if the particle swarm individual's "fate" is changed rather than their "state." Furthermore, PSO experiences partial optimism, which results in less precise measurements of its position and velocity in its Control. However, this algorithm does not solve the optimization or scattering problems. The flowchart for the PSO algorithm is shown in Figure 5.

\subsection{Artificial Neural Network}

The computational tool that represents nonlinear systems has been said to be ANN [31-33]. ANN consists of biological neurons, which contain weight and bias to interconnect each other by transferring signals. The weights related to input values go together with the learning rule in the training process. The output $y_{j}$ of ANN has given in Equation (11),

$$
y_{i}=f\left(\sum w_{i j} x_{i}+b\right)
$$

where $\mathrm{f}=$ activation function, $\mathrm{x}_{\mathrm{i}}=$ input signal and $\mathrm{w}_{\mathrm{ij}}=$ weight between input and output, $\mathrm{b}=$ bias value. The output neuron $\mathrm{E}$, obtained as follows,

$$
\mathrm{E}=\frac{1}{2} \sum_{\mathrm{i}}\left(\mathrm{y}_{\mathrm{di}}-\mathrm{y}_{\mathrm{i}}\right)^{2}
$$

where $y_{d i}=$ desired value of output neuron $i$ and $y_{i}=$ actual output. 


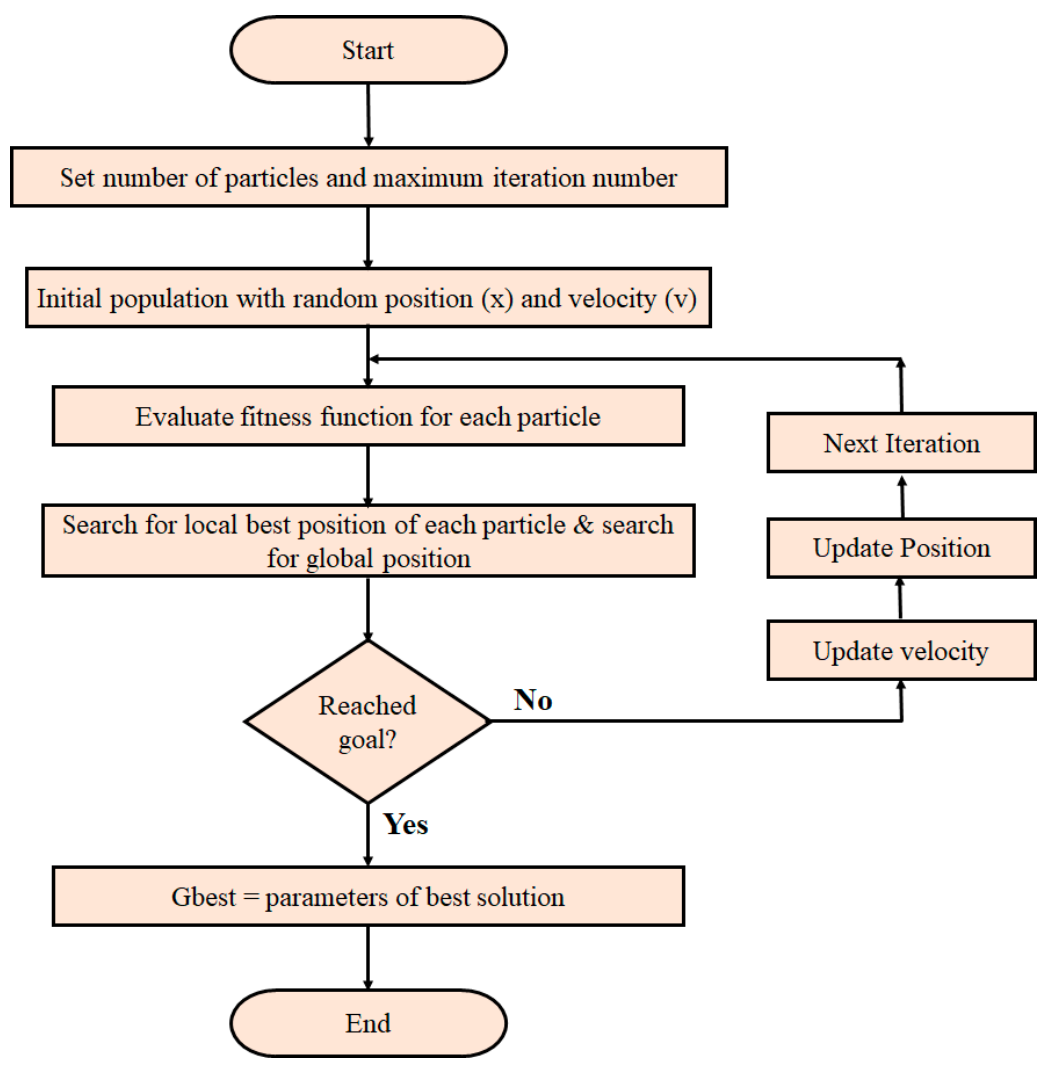

Figure 5. Flowchart of particle swarm optimization (PSO) Algorithm.

In this paper, a quasi-Newton back propagation algorithm has been used for weight mean square error (MSE). With the help of a minimum number of neurons per layer, maximum accuracy has been obtained by carrying out more trials. The ANN that is developed in this paper, the input layer contains 1 neuron, the hidden layer has 10 neurons, and the output layer has 1 neuron. The neurons in the input layer and the hidden layers' sigmoidal activation functions are used, and the neurons in the output layer linear activation function are used. The structure of ANN used in this paper is shown in Figures 6 and 7.

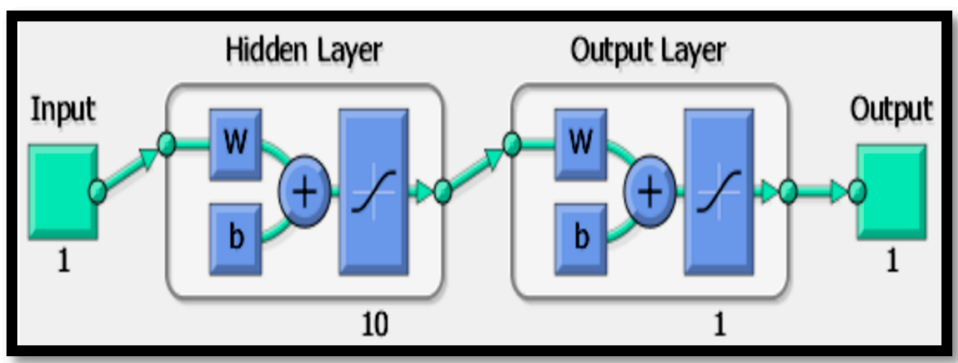

Figure 6. Design of ANN controller for the boost converter.

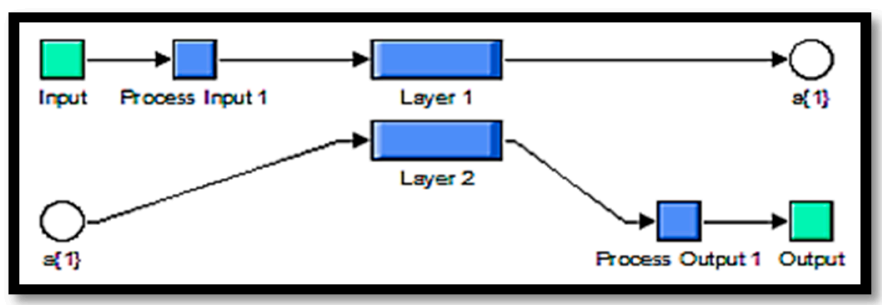

Figure 7. Simulink model of artificial neural network (ANN) chosen for the boost converter. 


\subsection{Fuzzy Logic Controller}

The linguistic variables and their ranges are determined with the help of the main control variables. With the help of these control variables, the fuzzy logic controller (FLC) [34-37] is designed. The human's specific intellect and understanding for developing the membership functions are essential for making the perception. Figures 8 and 9 depict an FLC-based MPPT controller and an FLC rule viewer and sur-face viewer, respectively. Consider the input variables error $\mathrm{E}(\mathrm{k})$ and shift in error $\mathrm{DE}$ when determining the fuzzy membership functions (k). As a result of these input signals, linguistic variables are obtained. Change of Control (Duty cycle D (k)) is the contribution of the fuzzy membership function. Figure 10 shows the proposed MPPT [38] control scheme with membership feature fuzzy controller for $\mathrm{E}(\mathrm{k}), \mathrm{DE}(\mathrm{k})$, and $\mathrm{D}(\mathrm{k})$. With the use of the intuition method, a triangular membership function was used to obtain $\mathrm{E}(\mathrm{k})$ membership values and $\mathrm{DE}(\mathrm{k})$. The $\mathrm{E}(\mathrm{k})$ and $\mathrm{DE}(\mathrm{k})(-2,2)$ intervals are set. To classify some unique input, a triangular style membership feature is proposed for an individual dominant fuzzy subset. Fuzzy rules for the hybrid (PV-FC) scheme are presented in Table 1.

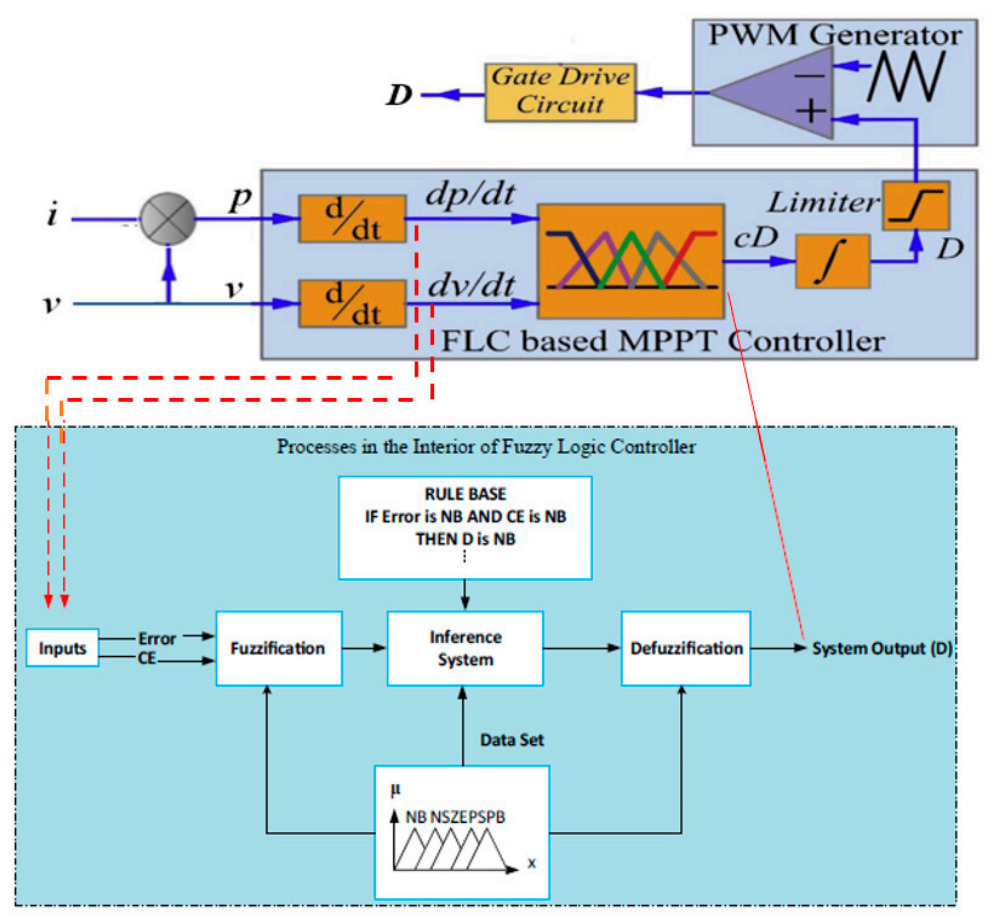

Figure 8. Fuzzy logic-based maximum power point tracking (MPPT) controller for boost converter.

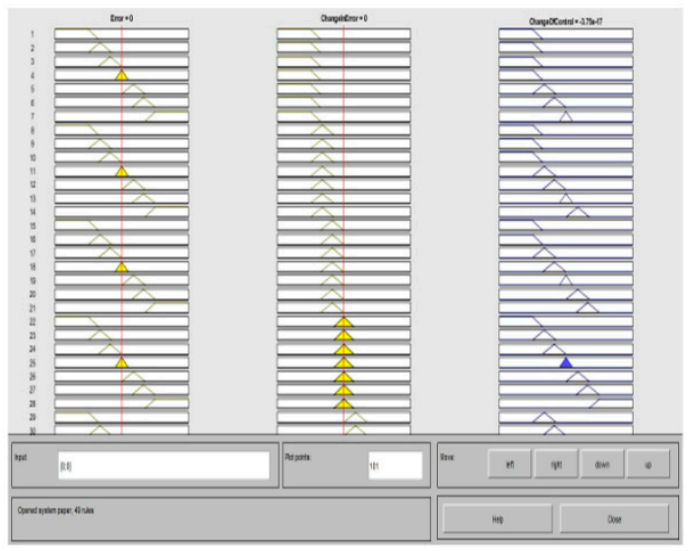

(a)

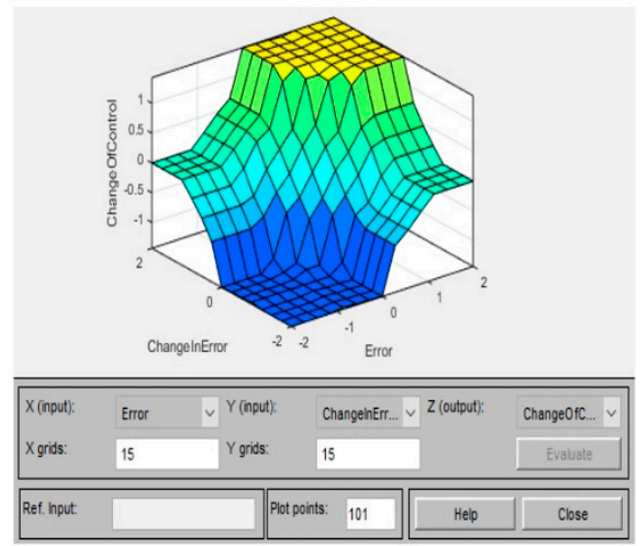

(b)

Figure 9. Fuzzy logic controller (a) rule viewer (b) surface viewer. 


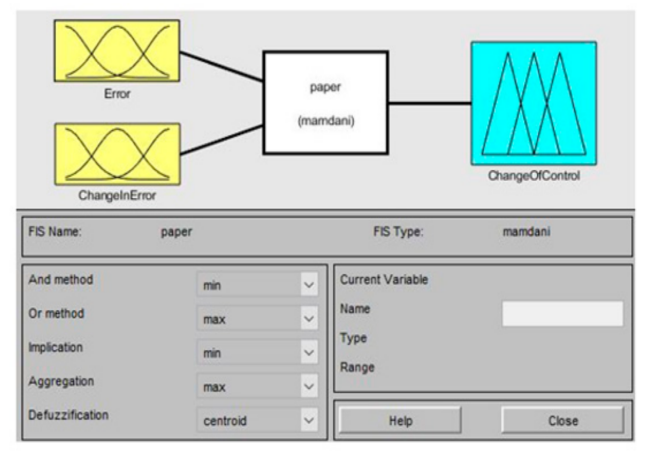

(a)

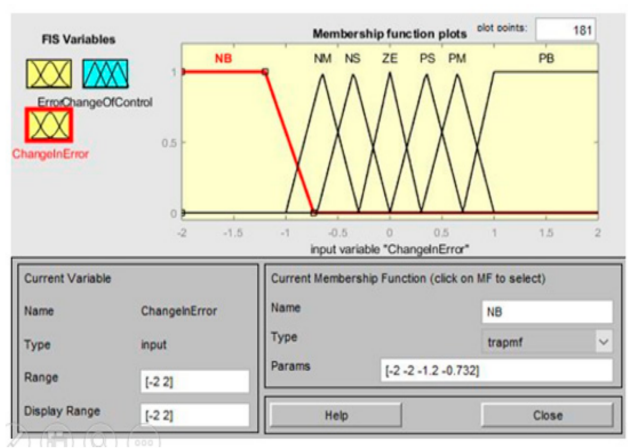

(c)

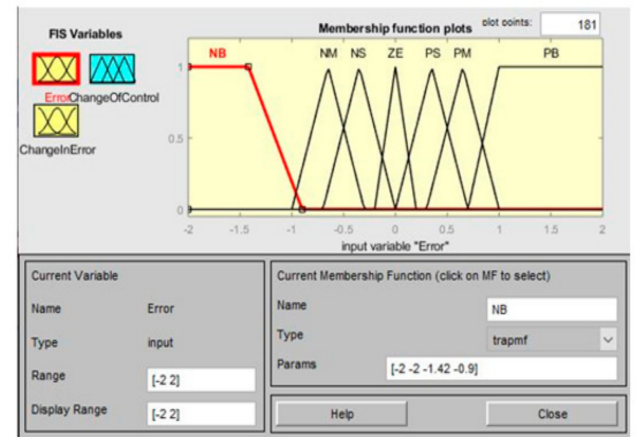

(b)

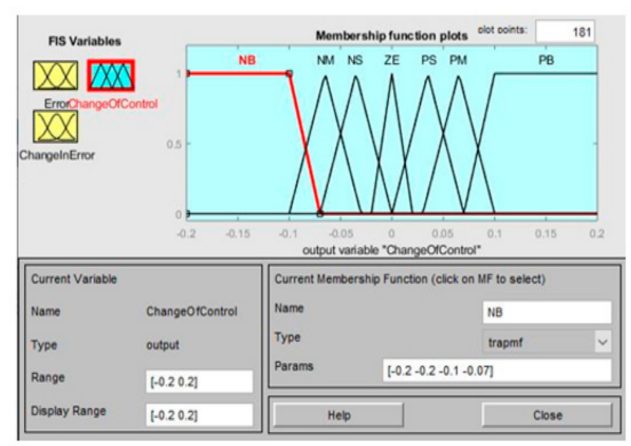

(d)

Figure 10. (a) Design of fuzzy (b) membership functions of input variable E (k) (c) membership functions for input variables DE (k) (d) membership functions of output change in duty cycle.

Table 1. Rules table of the fuzzy logic controller (FLC).

\begin{tabular}{cccccccc}
\hline $\mathbf{E}(\mathbf{k})$ & NB & NM & NS & ZE & PS & PM & PB \\
\cline { 1 - 5 } $\boldsymbol{y} \mathbf{E}(\mathbf{k})$ & & & & & & \\
\cline { 1 - 3 } NB & ZE & ZE & NS & NM & PM & PM & PB \\
NM & ZE & ZE & ZE & NS & PS & PM & PB \\
NS & ZE & ZE & ZE & ZE & PS & PM & PB \\
ZE & NB & NM & NM & ZE & PS & PM & PB \\
PS & PB & NM & NM & ZE & ZE & ZE & ZE \\
PM & NB & NM & NM & PS & ZE & ZE & ZE \\
PB & NB & NM & NM & PM & PS & ZE & ZE \\
\hline
\end{tabular}

\section{Simulink model of DC Microgrid}

The hybrid DC microgrid Simulink model using MATLAB comprises DC-DC boost converters, PV, FC, FLC, ANN, PSO-based MPPT method, and resistive load. This proposed hybrid DC microgrid has been developed with the help of MATLAB simulation software. The system parameters for PV, FC, boost converter, DC-DC bidirectional converter, supercapacitor, and battery are illustrated in Table 2. Figure 11 illustrates MATLAB Simulink model of hybrid DC microgrid, and Figures 12-14 show the subsystem of FC, DC-DC bidirectional converter and boost converter, model of FLC. 
Table 2. Renewable Energy Parameters Used for DC Microgrid.

\begin{tabular}{|c|c|c|}
\hline Parameters & Values & Name of the Component \\
\hline Temperature & $25^{\circ} \mathrm{C}$ & \\
\hline Irradiance & $1000 \mathrm{~W} / \mathrm{m}^{2}$ & \\
\hline $\begin{array}{l}\text { Series Connected Modules Per } \\
\text { String }\end{array}$ & 2 & Solar PV Module \\
\hline Parallel Strings & 4 & \\
\hline Open Circuit Voltage & $21 \mathrm{~V}$ & \\
\hline Short Circuit Current & $8 \mathrm{~A}$ & \\
\hline Number of Cells & 65 & Fuel Cell \\
\hline Nominal Stack Efficiency & $55 \%$ & \\
\hline Operating Temperature & $65^{\circ} \mathrm{C}$ & \\
\hline Nominal Air Flow Rate & $3001 \mathrm{pm}$ & \\
\hline Nominal Supply Pressure & $\begin{array}{l}\text { Fuel-1.5 bar } \\
\text { Air-1 bar }\end{array}$ & \\
\hline Nominal Composition & $99.95 \mathrm{H}_{2}, 21 \mathrm{O}_{2}, 1 \mathrm{H}_{2} \mathrm{O}$ in \% & \\
\hline Fuel Cell Resistance & $0.07833 \Omega$ & \\
\hline Nerst Voltage of one Cell & $1.1288 \mathrm{~V}$ & \\
\hline Input Resistance & $0.005 \Omega$ & Boost Converter \\
\hline Inductor & $3 \mathrm{mH}$ & \\
\hline Input Capacitor & $0.02 \mu \mathrm{F}$ & \\
\hline IGBT & 1 No. & \\
\hline DC-Link & $300 \mu \mathrm{F}$ & \\
\hline Input Inductance & $1.5 \mathrm{mH}$ & $\begin{array}{l}\text { DC-DC Bidirectional } \\
\text { Converter }\end{array}$ \\
\hline IGBT & 2 Nos. & \\
\hline Output Resistance & $0.5 \Omega$ & \\
\hline Output Inductance & $0.35 \mathrm{mH}$ & \\
\hline Rated Capacitance & $29 \mathrm{~F}$ & Super Capacitor \\
\hline Equivalent DC Series Resistance & $0.03 \Omega$ & \\
\hline Rated Voltage & $32 \mathrm{~V}$ & \\
\hline Number Series Capacitor & 1 & \\
\hline Number of Parallel Capacitor & 1 & \\
\hline Initial Voltage & $32 \mathrm{~V}$ & \\
\hline Operating Temperature & $25^{\circ} \mathrm{C}$ & \\
\hline Type & lithium-Ion & Battery \\
\hline Nominal Voltage & $24 \mathrm{~V}$ & \\
\hline Rated capacity & $14 \mathrm{Ah}$ & \\
\hline Initial state-of-charge & $50 \%$ & \\
\hline Cut-off voltage & $18 \mathrm{~V}$ & \\
\hline
\end{tabular}

Figure $15 \mathrm{a}, \mathrm{b}$ shows the solar PV irradiance of $980 \mathrm{~W} / \mathrm{m}^{2}$ for $\mathrm{t}<1 \mathrm{~s}$ and $800 \mathrm{~W} / \mathrm{m}^{2}$ for $\mathrm{t}>1 \mathrm{~s}$ with constant temperature $\mathrm{T}=25^{\circ} \mathrm{C}$ and nominal charging and discharging characteristics of an energy storage system.

In this proposed system, the hybrid DC microgrid comprises solar PV with a boost converter, FC with a boost converter, Supercapacitor with bidirectional converter, and battery with bidirectional converter. The aforementioned simulations comprise FLC, ANN, and PSO-based MPPT. Figures 16-18 illustrate solar PV power with (FLC, ANN, and PSO) and without MPPT controller. 


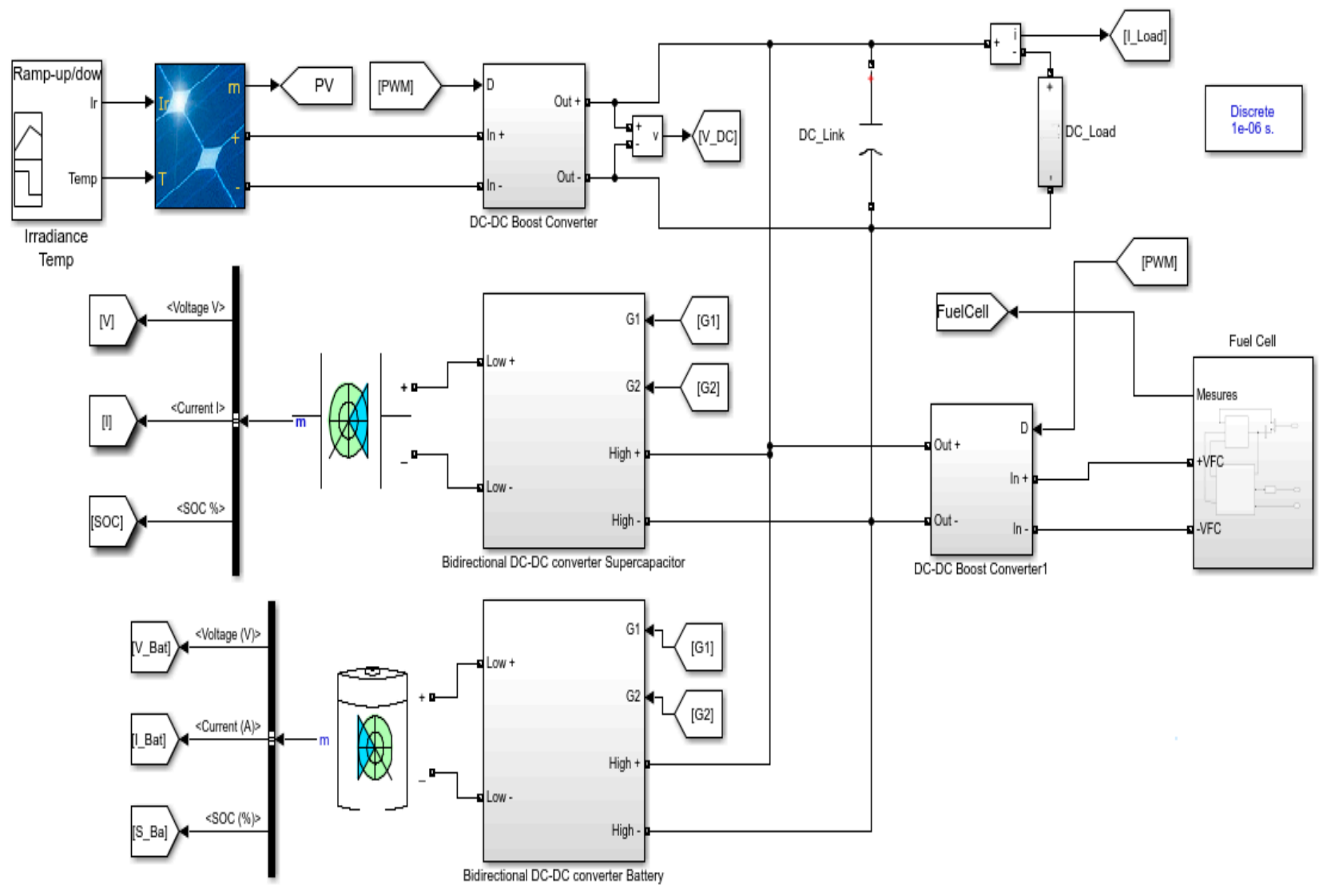

Figure 11. MATLAB/Simulink model for hybrid DC microgrid.

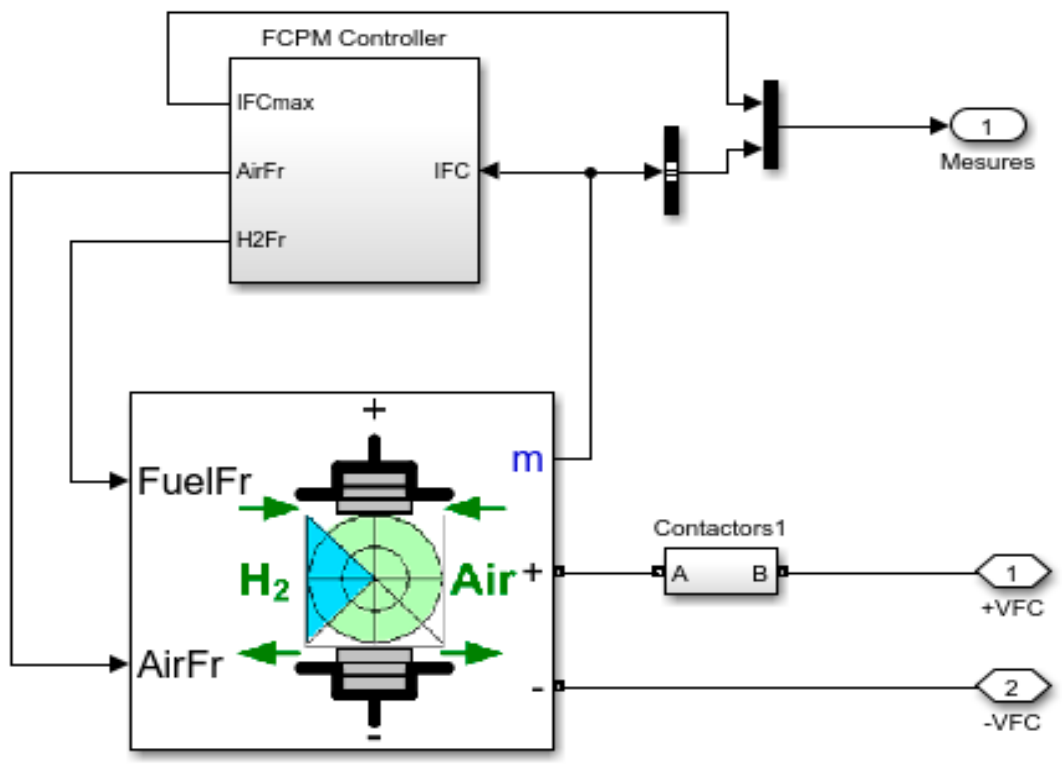

Figure 12. Fuel cell model of a DC microgrid. 


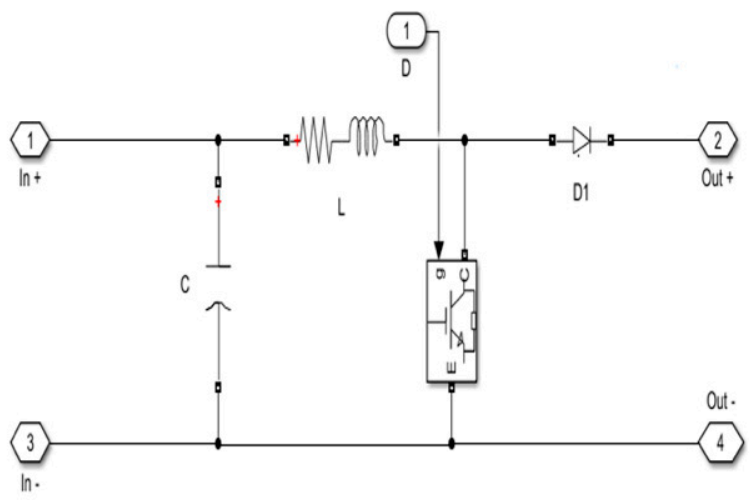

(a)

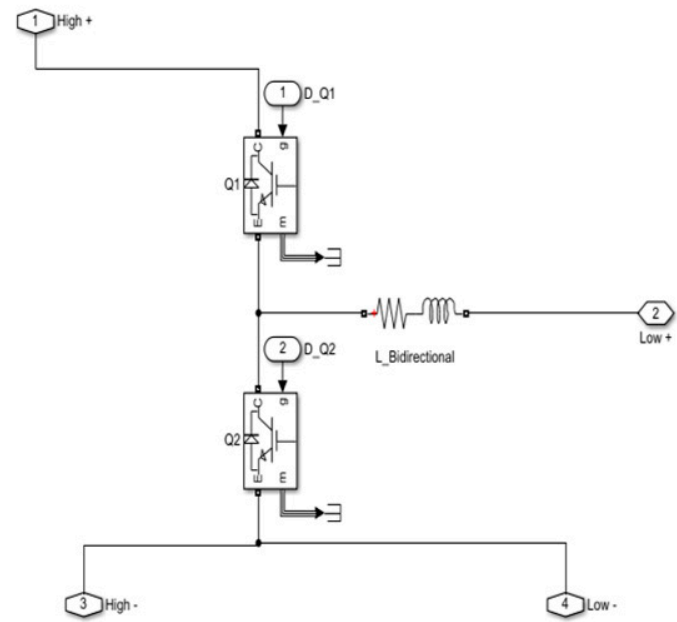

(b)

Figure 13. (a) The subsystem of boost converter (b) Subsystem of bidirectional converter for ESS.

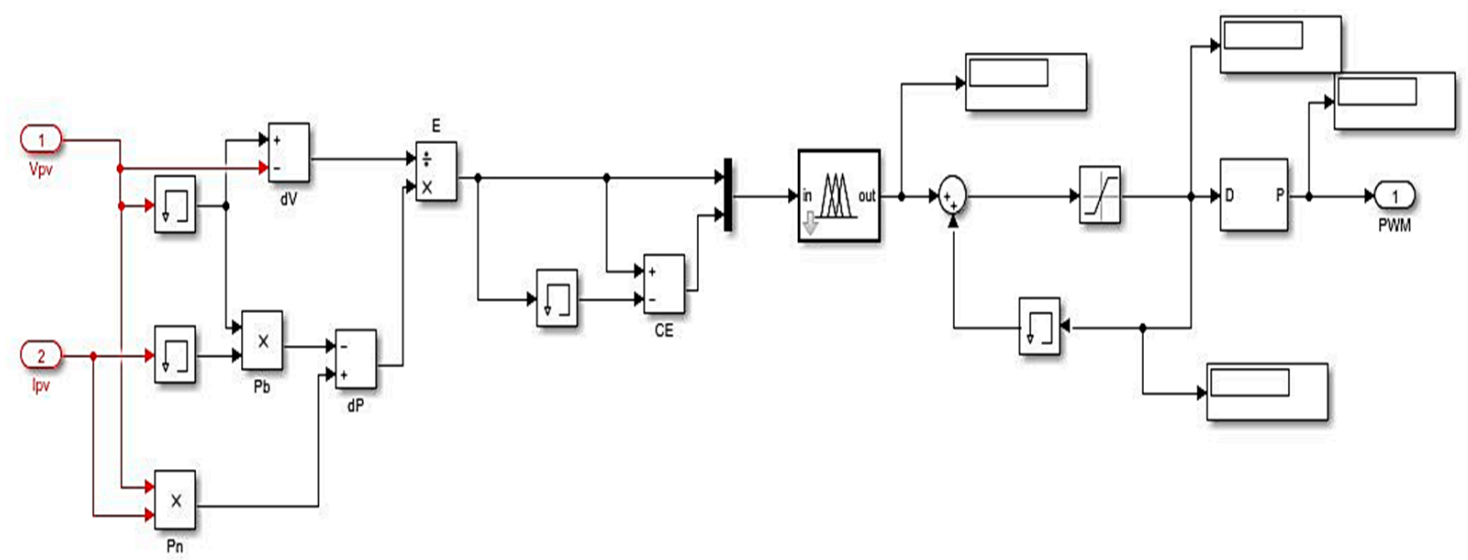

Figure 14. The subsystem of FLC.

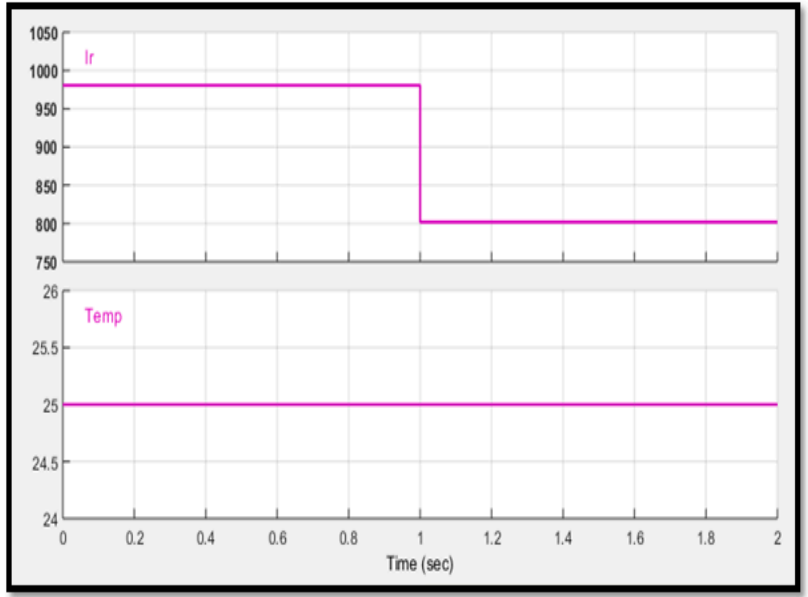

(a)

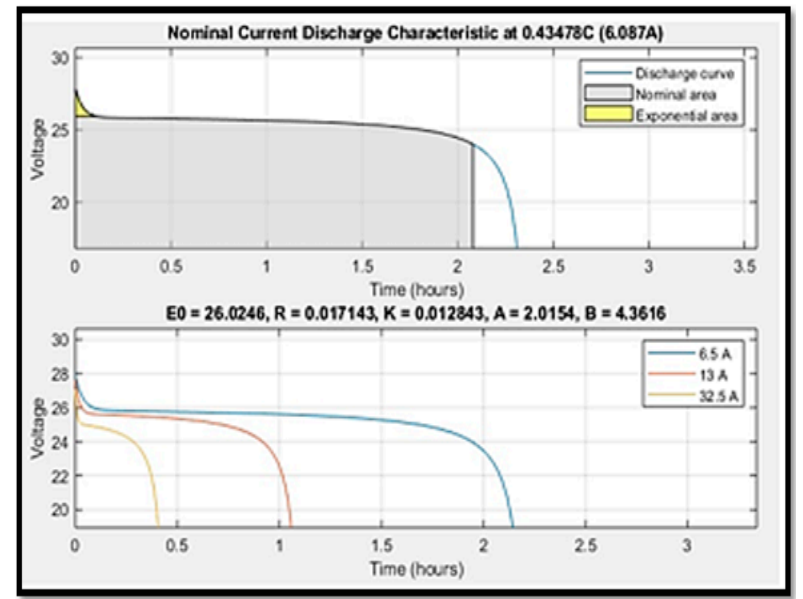

(b)

Figure 15. (a) Irradiance and temperature for solar PV (b) nominal current discharging of a battery. 


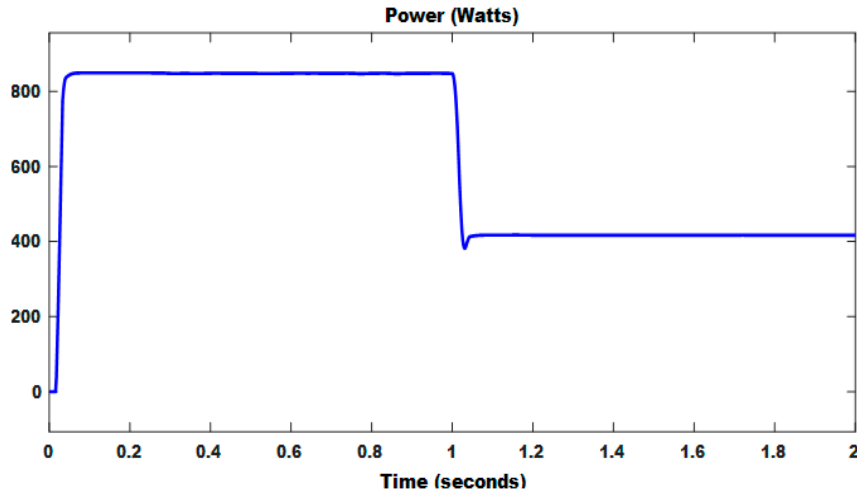

(a)

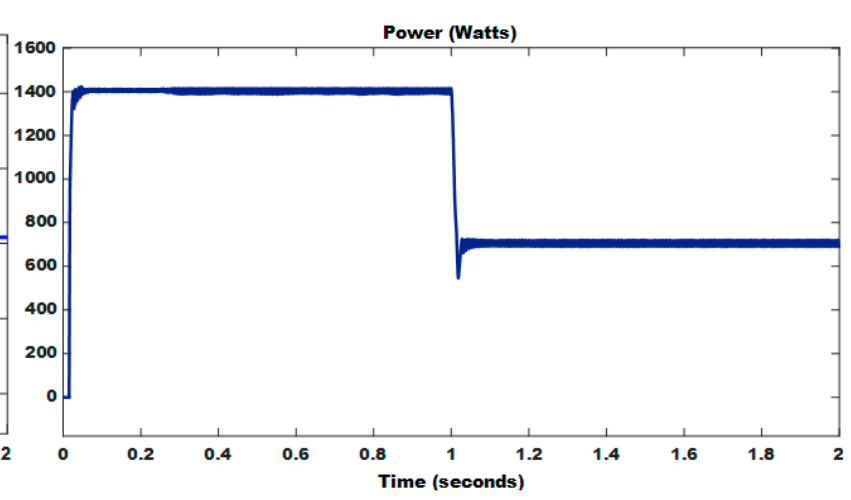

(b)

Figure 16. (a) PV power without MPPT controller (b) PV power with FLC.

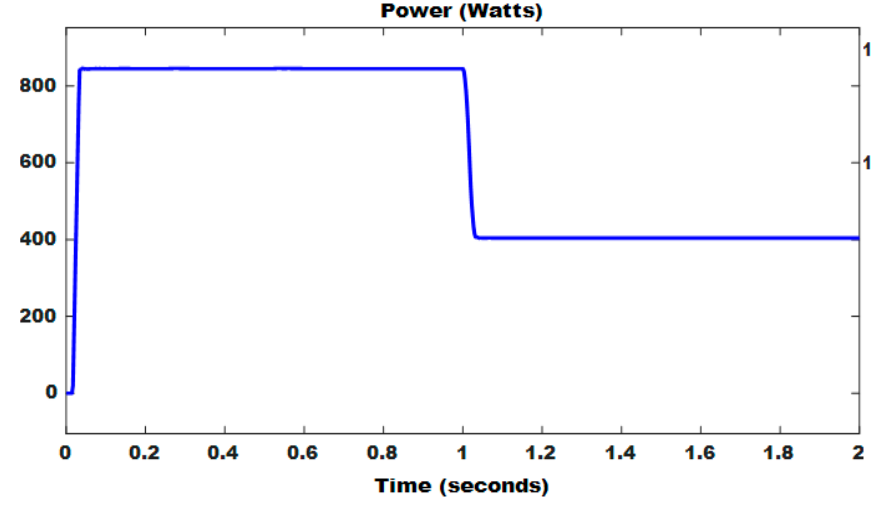

(a)

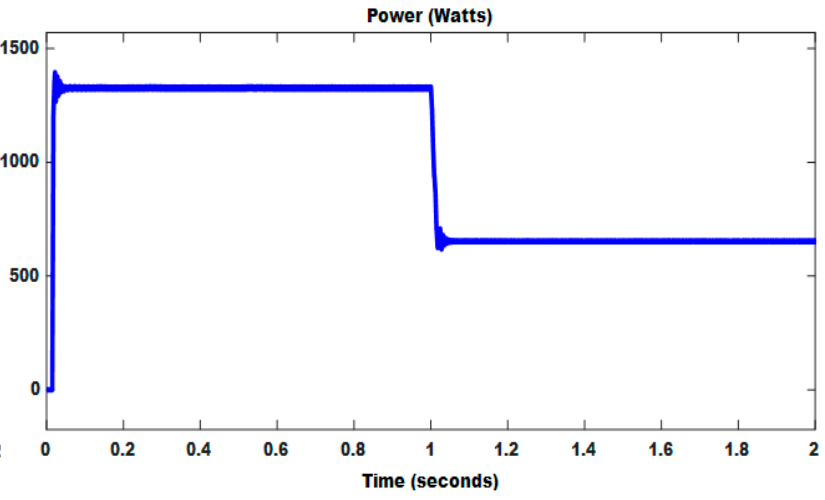

(b)

Figure 17. (a) PV power without MPPT controller (b) PV power with ANN.

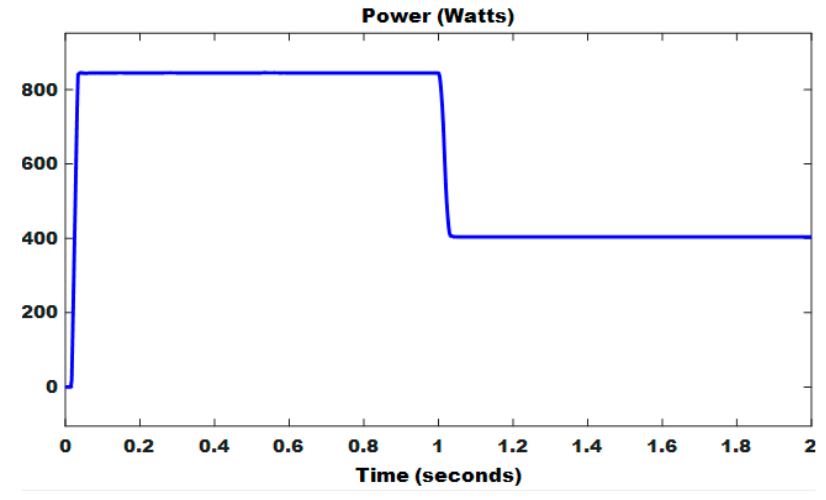

(a)

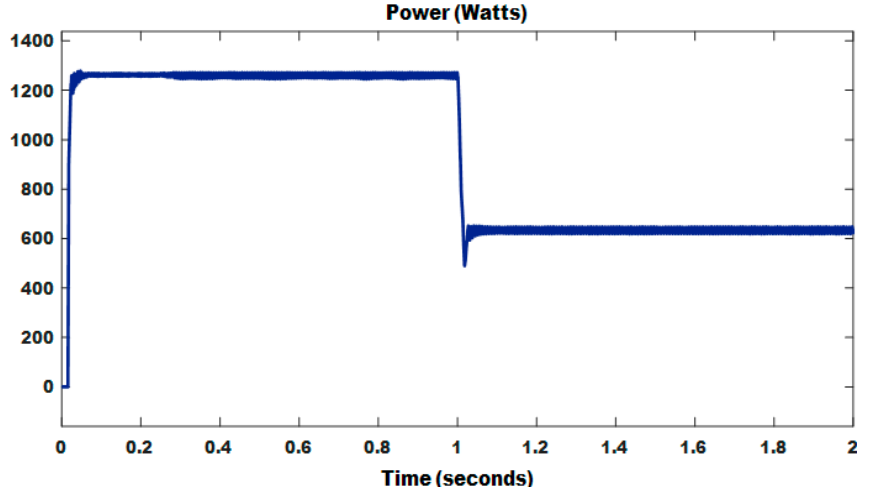

(b)

Figure 18. (a) PV power without MPPT controller (b) PV power with PSO.

Similarly, Figure 19 shows the output power of FC with (FLC, ANN and PSO) and without an MPPT controller. Figures 20 and 21 show the output voltage, current, power, and state of charge (SOC) of battery and supercapacitor with the use of a bidirectional converter. Using FLC, the performance of solar PV has risen to $1402 \mathrm{~W}$ from $845 \mathrm{~W}$, which is a rise of $66 \%$, then $\mathrm{FC}$ has raised to $1278 \mathrm{~W}$ from $787 \mathrm{~W}$, which is a rise of $62 \%$. Using ANN, the performance of solar PV has risen to $1335 \mathrm{~W}$ to $845 \mathrm{~W}$, which is a rise of $58 \%$ then FC has raised to $1208 \mathrm{~W}$ from $787 \mathrm{~W}$, which is a rise of $53 \%$. Similarly, by using the PSO 
algorithm, the performance of solar PV has raised to $1260 \mathrm{~W}$ from $845 \mathrm{~W}$, which is a rise of $49 \%$ then FC has raised to $1188 \mathrm{~W}$ from $787 \mathrm{~W}$, which is a rise of $51 \%$.

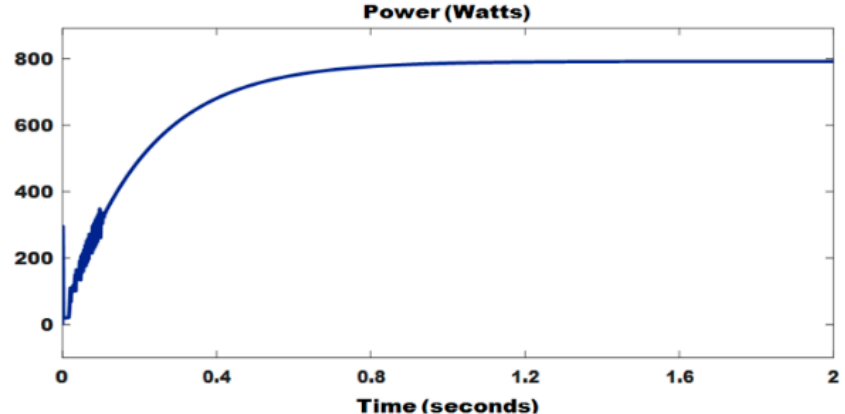

(a)

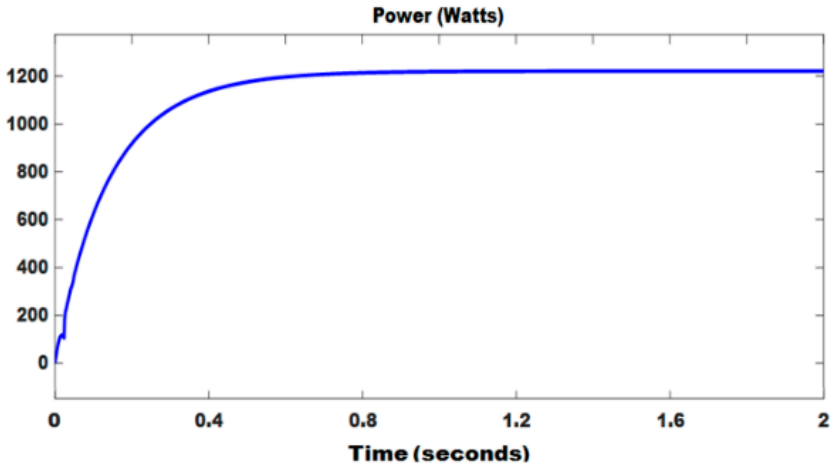

(c)

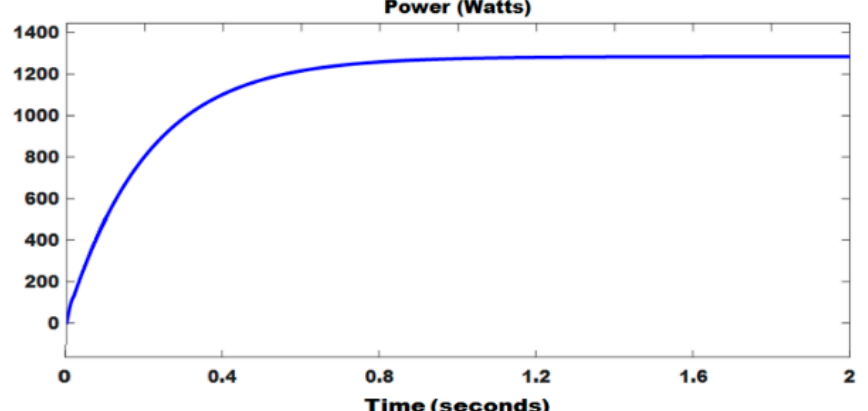

(b)

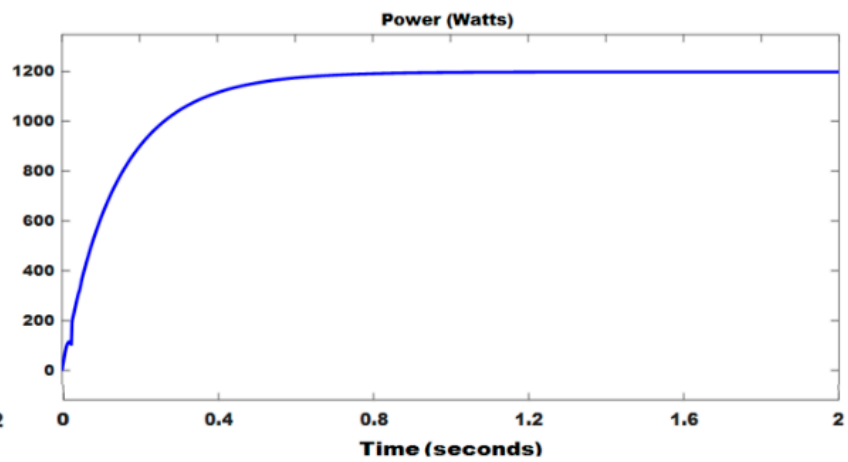

(d)

Figure 19. (a) Output power of FC without MPPT (b) Output power of FC with FLC-based MPPT (c) Output power of FC with ANN-based MPPT (d) Output power of FC with PSO-based MPPT.

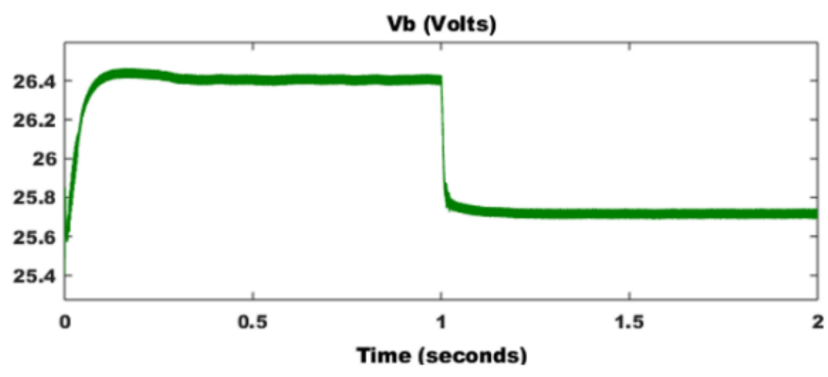

(a)

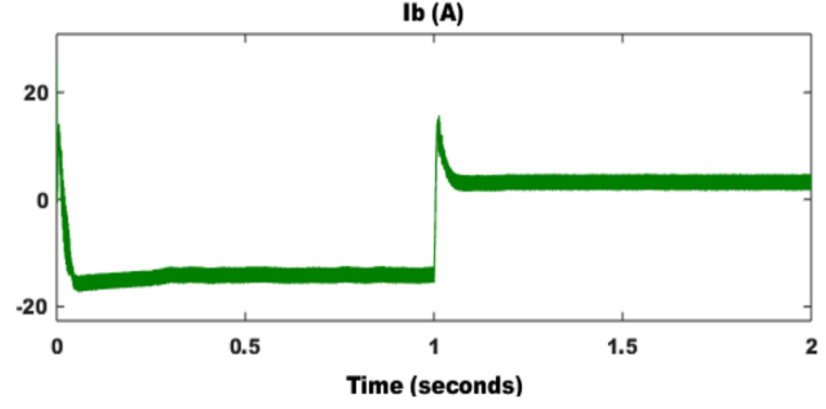

(c)

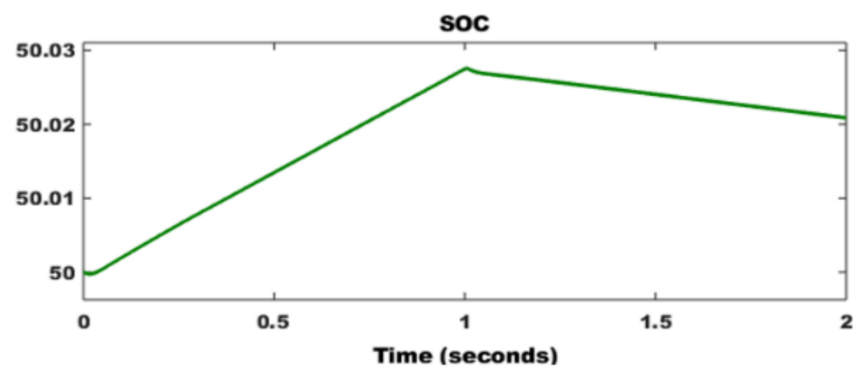

(b)

$\mathbf{P b}$ (watts)

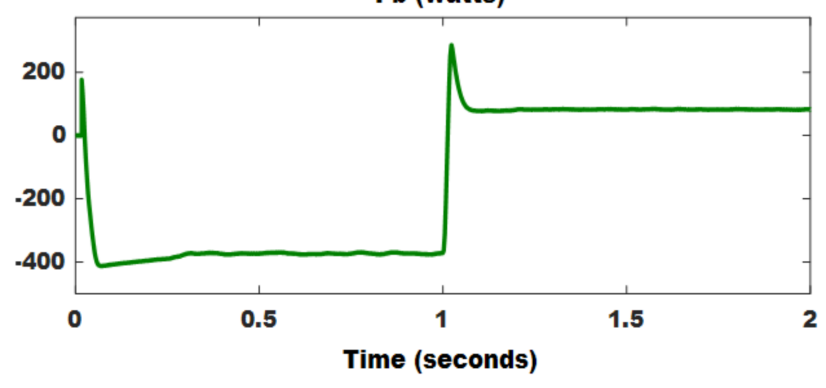

(d)

Figure 20. (a) Battery output voltage (b) SOC of battery (c) battery output current (d) battery output power. 


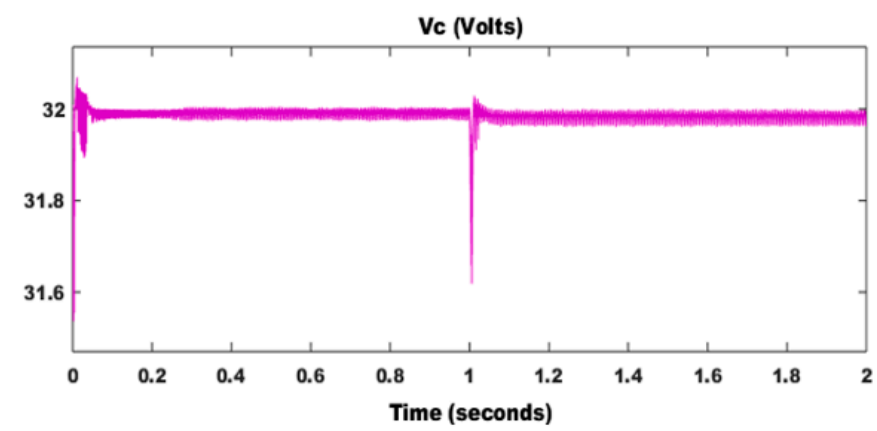

(a)

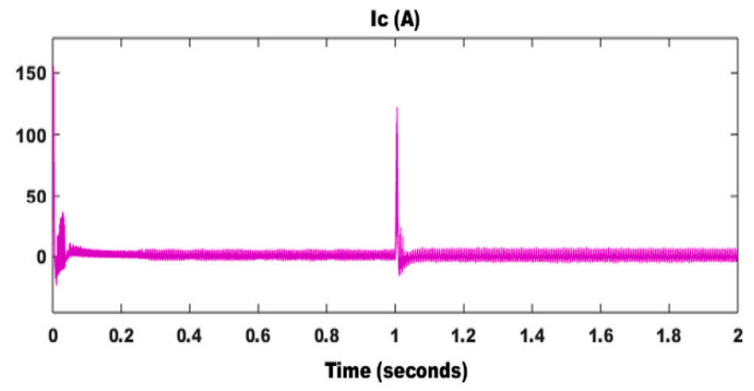

(c)

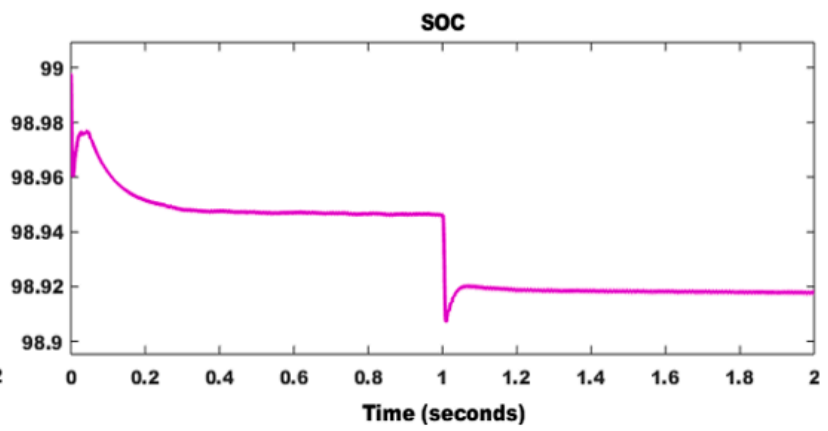

(b)

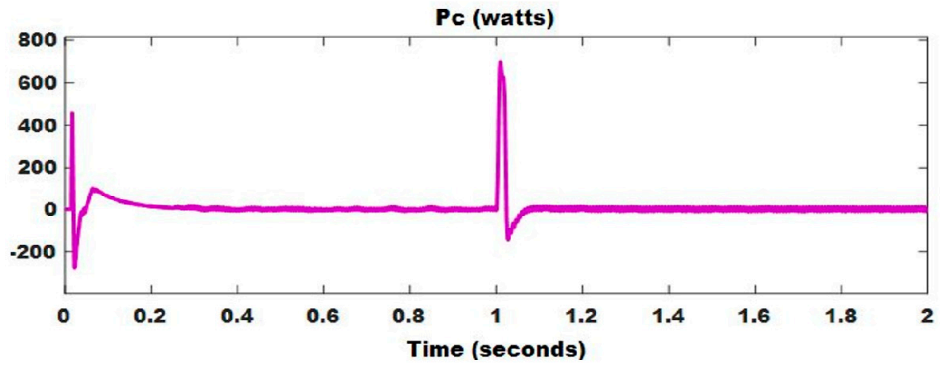

(d)

Figure 21. (a) The voltage of Supercapacitor (b) SOC of Super Capacitor (c) Current of Super Capacitor (d) Power of Super Capacitor.

It clears that FLC gives the best performance for this proposed hybrid Dc microgrid when compared to ANN and PSO algorithm. Table 3 gives the comparative analysis of power for PV and FC without MPPT and with FLC, ANN, and PSO algorithm-based MPPT.

Table 3. Comparison table for hybrid (PV-FC) power with and without MPPT techniques.

\begin{tabular}{ccccc}
\hline & \multicolumn{4}{c}{ Power (Watt) } \\
\cline { 2 - 5 } Sources & \multirow{2}{*}{ Without MPPT } & \multicolumn{3}{c}{ With MPPT Control } \\
\cline { 2 - 5 } & & FLC & ANN & PSO \\
\hline PV & 845 & 1402 & 1335 & 1260 \\
FC & 787 & 1278 & 1208 & 1194 \\
\hline
\end{tabular}

Figures 22-24 show the Simulink output voltage of $150 \mathrm{~V}$, current of $15 \mathrm{~A}$ and power of $2250 \mathrm{~W}$ for hybrid DC microgrid with a comparative analysis of FLC, ANN and PSO algorithm-based MPPT controller. Table 4 shows the comparison of settling time, overshoot, and undershoot for the proposed hybrid DC microgrid with the help of FLC, ANN, and PSO algorithm. The simulation results, which were obtained for the hybrid DC microgrid, tabulated in Table 4. Hence, with the help of different controllers, the enactment of the hybrid structure has been detected and analyzed. The Simulation analysis for hybrid DC microgrid using MATLAB/Simulink has been done to compute the maximum power of the DC load (resistive load) with different controllers. 


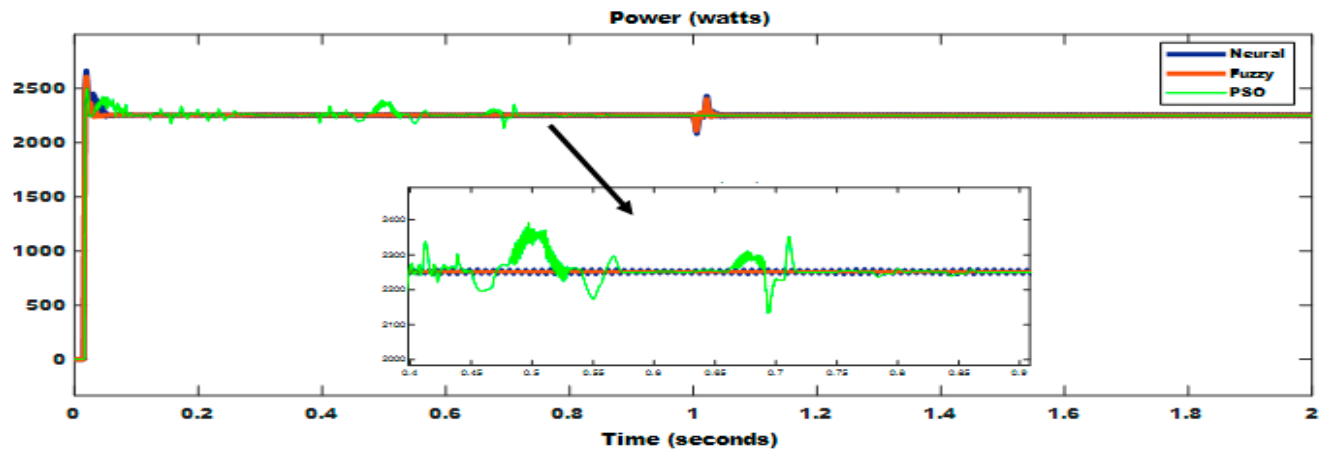

Figure 22. Load power with fuzzy, neuro and PSO.

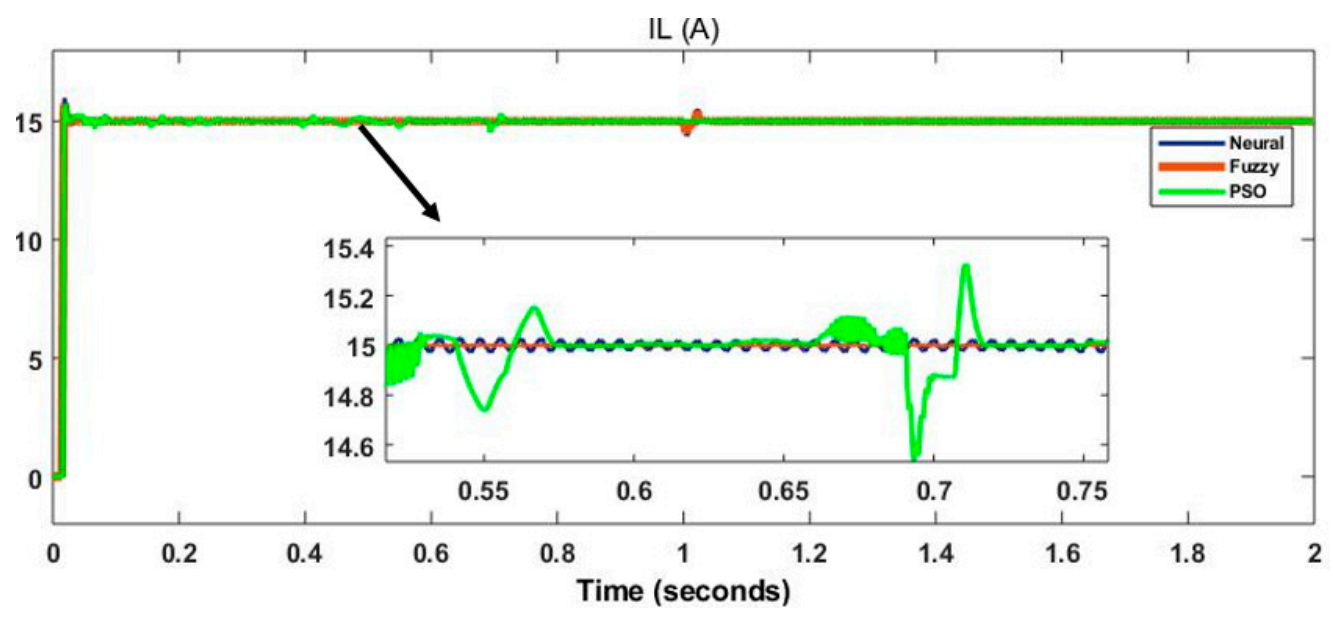

Figure 23. Load current with fuzzy, neuro, and PSO.

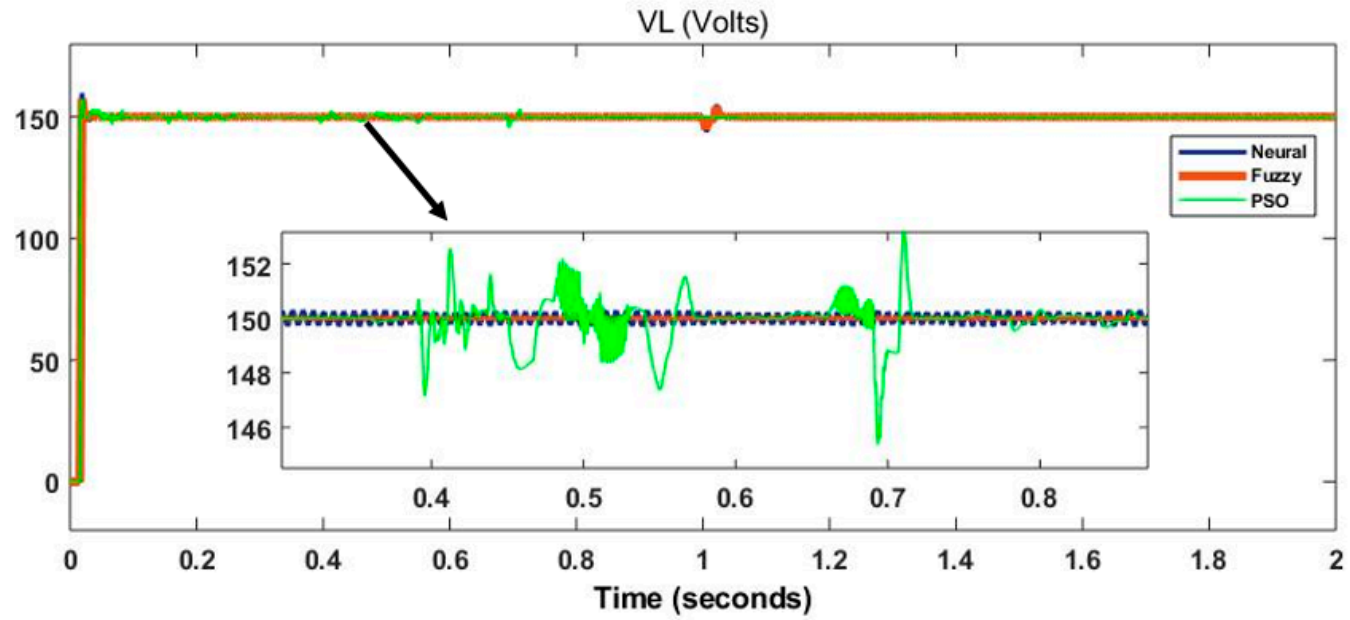

Figure 24. Load voltage with fuzzy, neuro, and PSO.

Table 4. Performance of load parameters with different controllers (FLC, ANN, and PSO).

\begin{tabular}{cccc}
\hline Control Technique & \multicolumn{3}{c}{ Performance Parameters after MPPT } \\
\hline & Under Shoot (W) & Over Shoot (W) & Settling Time (s) \\
\hline PSO & 1442 & 1667 & 0.650 \\
Neural Network & 1490 & 1775 & 0.054 \\
Fuzzy & 1491 & 1735 & 0.035 \\
\hline
\end{tabular}




\section{Conclusions}

In this paper, a hybrid DC microgrid with various control techniques has been proposed to achieve maximum power point in solar PV and FC. The MPPT method improves the settling time of the proposed hybrid DC microgrid, according to the results obtained using different control techniques such as FLC, ANN, and PSO algorithm. When compared to other control methods, FLC has a higher efficiency rating. The results show that the fuzzy MPPT approach for forecasting hybrid DC microgrid output has a high level of precision, effectiveness, and reliability. This research has been applied to both grid and stand-alone systems. As a result of this research into different control techniques for MPPT systems, it is now possible to choose a particular MPPT process for various applications. We will investigate the possibility of implementing the appropriate control methods to other types of DC-DC converters as well as to control a DC microgrid with advanced DC-DC converter topologies in future research.

Author Contributions: Conceptualization. S.V., V.I.; Methodology. S.V., V.I., V.S.; Software. S.V., Formal Analysis. S.V., V.I., and Y.T.; Investigation. S.V.; Resources. V.S., and R.K.; Data Curation. S.V., V.I., and S.N.; Writing-original draft preparation. S.V., V.I.; Writing-reviewing and editing. S.V., V.I., V.S.; Visualization. V.I.; Supervision. R.K., S.N. All authors provided critical feedback and collaborated in the paper. All authors have read and agreed to the published version of the manuscript.

Funding: This research received no external funding.

Institutional Review Board Statement: Not applicable.

Informed Consent Statement: Informed Consent was obtained from all subjects involved in the study.

Data Availability Statement: Not applicable.

Conflicts of Interest: The authors declare no conflict of interest.

\section{References}

1. Gandini, D.; de Almeida, A.T. Direct current microgrids based on solar power systems and storage optimization, as a tool for cost-effective rural electrification. Renew. Energy 2017, 111, 275-283. [CrossRef]

2. Hirsch, A.; Parag, Y.; Guerrero, J. Microgrids: A review of technologies, key drives and outstanding issues. Renew. Sustian. Energy Rev. 2018, 90, 402-411. [CrossRef]

3. Liu, Z.; Su, M.; Sun, Y.; Yuan, W.; Han, H.; Feng, J. Existence and Stability of Equilibrium of DC Microgrid with Constant Power Loads. IEEE Trans. Power Syst. 2018, 33, 6999-7010. [CrossRef]

4. Cheng, Z.; Li, Z.; Li, S.; Gao, J.; Si, J.; Das, H.S.; Dong, W. A novel cascaded control to improve stability and inertia of parallel buck-boost converters in DC microgrid. Int. J. Electr. Power Energy Syst. 2020, 119, 105950. [CrossRef]

5. Eid, A. Utility integration of PV-wind-fuel cell hybrid distributed generation systems under variable load demands. Int. J. Electr. Power Energy Syst. 2014, 62, 689-699. [CrossRef]

6. Srinivasan, M.; Kwasinski, A. Control analysis of parallel DC-DC converters in a DC microgrid with constant power loads. Int. J. Electr. Power Energy Syst. 2020, 122, 106207. [CrossRef]

7. Liu, Z.; Zhao, J.; Zou, Z. Impedance Modeling, dynamic Analysis and damping enhancement for DC Microgrid with multiple types of loads. Electr. Power Energy Syst. 2020, 122, 1-12. [CrossRef]

8. Armghan, H.; Yang, M.; Wang, M.; Ali, N.; Armghan, A. Nonlinear integral backstepping based control of a DC microgrid with renewable generation and energy storage systems. Int. J. Electr. Power Energy Syst. 2020, 117, 105613. [CrossRef]

9. Ahmed, O.A.; Bleijs, J.A.M. Power Flow Control Methods for an Ultra capacitor Bidirectional Converter in DC Microgrids-A Comparative Study. Renew. Sustian. Energy Rev. 2013, 26, 727-738. [CrossRef]

10. Arif, M.T.; Oo, A.M.T.; Ali, A.B.M.S.; Safiullah, G.M. Significance of storage on solar photovoltaic system-A Residential load case study in Australia. Smart Grid Renew. Energy 2013, 4, 167-180. [CrossRef]

11. Kyriakarakos, G.; Dounis, A.I.; Arvanitis, K.G.; Papadakis, G. A fuzzy logic energy management system for polygeneration microgrids. Renew. Energy 2012, 41, 315-327. [CrossRef]

12. Yaici, W.; Entchev, E. Adaptive Neuro-Fuzzy Inference System modelling for performance prediction of solar thermal energy system. Renew. Energy 2016, 86, 302-315. [CrossRef]

13. Oshaba, A.S.; Ali, E.S.; Elazim, S.M.A. PI controller design for MPPT of photovoltaic system supplying SRM via BAT search algorithm. Neural Comput. Appl. 2017, 28, 651-667. [CrossRef]

14. Venkateswari, R.; Sreejith, S. Factors influencing the efficiency of photovoltaic system. Renew. Sustain. Energy Rev. 2019, 101, 376-394. [CrossRef] 
15. Youssef, A.; El Telbany, M.; Zekry, A. Reconfigurable generic FPGA implementation of fuzzy logic controller for MPPT of PV systems. Renew. Sustain. Energy Rev. 2018, 82, 1313-1319. [CrossRef]

16. Enany, M.A.; Farahat, M.A.; Nasr, A. Modeling and evaluation of main maximum power point tracking algorithms for photovoltaics systems. Renew. Sustain. Energy Rev. 2016, 58, 1578-1586. [CrossRef]

17. Babaa, S.E.; Armstrong, M.; Pickert, V. Overview of Maximum Power Point Tracking Control Methods for PV systems. J. Power Energy Eng. 2014, 2, 59-72. [CrossRef]

18. Costano, L.; Vitelli, M. A Novel MPPT technique for single stage grid connected PV systems: T4S. Energies $2019,12,4501$. [CrossRef]

19. Khan, M.J.; Mathew, L. Fuzzy logic controller-based MPPT for hybrid photo-voltaic/wind/fuel cell power system. Neural Comput. Appl. 2018, 31, 6331-6344. [CrossRef]

20. Kharb, R.K.; Shimi, S.; Chatterji, S.; Ansari, F. Modeling of solar PV module and maximum power point tracking using ANFIS. Renew. Sustain. Energy Rev. 2014, 33, 602-612. [CrossRef]

21. Rezvani, A.; Gandomkar, M. Simulation and control of intelligent photovoltaic system using new hybrid fuzzy-neural method. Neural Comput. Appl. 2016, 28, 2501-2518. [CrossRef]

22. Deniz, E. ANN-based MPPT algorithm for solar PMSM drive system fed by direct-connected PV array. Neural Comput. Appl. 2016, 28, 3061-3072. [CrossRef]

23. Yap, W.K.; Karri, V. An off-grid hybrid PV/diesel model as a planning and design tool, incorporating dynamic and ANN modelling techniques. Renew. Energy 2015, 78, 42-50. [CrossRef]

24. Sundarabalan, C.K.; Puttagunta, Y.; Vignesh, V. Fuel cell integrated unified power quality conditioner for voltage and current reparation in four-wire distribution grid. IET Smart Grid 2019, 2, 60-68. [CrossRef]

25. Liu, H.; Chen, J.; Hissel, D.; Su, H. Short-term Prognostics of PEM Fuel Cells: A Comparative and Improvement Study. IEEE Trans. Ind. Electron. 2019, 66, 6077-6086. [CrossRef]

26. Garcia, P.; Garcia, C.A.; Fernandez, L.M.; Llorens, F.; Jurado, F. ANFIS-Based Control of a Grid-Connected Hybrid System Integrating Renewable Energies, Hydrogen and Batteries. IEEE Trans. Ind. Inform. 2013, 10, 1107-1117. [CrossRef]

27. Daud, W.; Rosli, R.; Majlan, E.H.; Hamid, S.; Mohamed, R.; Husaini, T. PEM fuel cell system control: A review. Renew. Energy 2017, 113, 620-638. [CrossRef]

28. Osório, G.; Matias, J.; Catalão, J.P.S. Short-term wind power forecasting using adaptive neuro-fuzzy inference system combined with evolutionary particle swarm optimization, wavelet transform and mutual information. Renew. Energy 2015, 75, 301-307. [CrossRef]

29. Bharti, O.P.; Saket, R.K.; Nagar, S.K. Controller design for doubly fed induction generator using particle swarm optimization technique. Renew. Energy 2017, 114, 1394-1406. [CrossRef]

30. Kerdphol, T.; Qudaih, Y.; Mitani, Y. Optimum battery energy storage system using PSO considering dynamic demand response for microgrids. Int. J. Electr. Power Energy Syst. 2016, 83, 58-66. [CrossRef]

31. Aldair, A.A.; Obed, A.A.; Halihal, A.F. Design and implementation of ANFIS-reference model controller based MPPT using FPGA for photovoltaic system. Renew. Sustain. Energy Rev. 2018, 82, 2202-2217. [CrossRef]

32. Ozçelep, Y.; Sevgen, S.; Samli, R. A study on the hydrogen consumption calculation of proton exchange membrane fuel cells for linearly increasing loads: Artificial Neural Network vs. Multiple linear regression. Renew. Energy 2020, 156, 570-578. [CrossRef]

33. Chaabene, M.; Ben Ammar, M. Neuro-fuzzy dynamic model with Kalman filter to forecast irradiance and temperature for solar energy systems. Renew. Energy 2008, 33, 1435-1443. [CrossRef]

34. Silveira, A.M.; Araújo, R.E. A new approach for the diagnosis of different types of faults in dc-dc power converters based on inversion method. Electr. Power Syst. Res. 2020, 180, 106103. [CrossRef]

35. Yilmaz, U.; Kircay, A.; Borekci, S. PV system fuzzy logic MPPT method and PI control as a charge controller. Renew. Sustain. Energy Rev. 2018, 81, 994-1001. [CrossRef]

36. Ozdemir, S.; Altin, N.; Sefa, I. Fuzzy logic based MPPT controller for high conversion ratio quadratic boost converter. Int. J. Hydrogen Energy 2017, 42, 17748-17759. [CrossRef]

37. Danandeh, M.; Mousavi, S.M. Comparative and comprehensive review of maximum power point tracking methods for PV cells. Renew. Sustain. Energy Rev. 2018, 82, 2743-2767. [CrossRef]

38. Yilmaz, U.; Turksoy, O.; Teke, A. Improved MPPT method to increase accuracy and speed in photovoltaic systems under variable atmospheric conditions. Electr. Power Energy Syst. 2019, 113, 634-651. [CrossRef] 